\title{
A Tetra(Ethylene Glycol) Derivative of Benzothiazole Aniline Enhances Ras-Mediated Spinogenesis
}

\author{
Andrea Megill, ${ }^{1 \star}$ Taehee Lee, ${ }^{2 \star}$ Amanda Marie DiBattista, ${ }^{2}$ Jung Min Song, ${ }^{2}$ Matthew H. Spitzer, ${ }^{2}$ Mark Rubinshtein, ${ }^{5}$ \\ Lila K. Habib, ${ }^{6}$ Christina C. Capule, ${ }^{5}$ Michael Mayer, ${ }^{7}$ R. Scott Turner, ${ }^{3}$ Alfredo Kirkwood, ${ }^{1}$ Jerry Yang, ${ }^{5}$ \\ Daniel T. S. Pak, ${ }^{4}$ Hey-Kyoung Lee, ${ }^{1}$ and Hyang-Sook Hoe ${ }^{2,3,8}$ \\ ${ }^{1}$ Department of Neuroscience, Johns Hopkins University, Baltimore, Maryland 20218, Departments of ${ }^{2}$ Neuroscience, ${ }^{3}$ Neurology, and ${ }^{4} \mathrm{Pharmacology}$, \\ Georgetown University Medical Center, Washington, DC 20057, Departments of ${ }^{5}$ Chemistry and Biochemistry, and ${ }^{6}$ Bioengineering, University of \\ California, San Diego, La Jolla, California 92093, ${ }^{7}$ Departments of Biomedical Engineering and Chemical Engineering, University of Michigan, Ann Arbor, \\ Michigan 48109, and ${ }^{8}$ Korea Brain Research Institute, Jung-gu, Daegu, Korea 700 - 010
}

The tetra(ethylene glycol) derivative of benzothiazole aniline, $B T A-E_{4}$, is a novel amyloid-binding small molecule that can penetrate the blood- brain barrier and protect cells from $\mathrm{A} \beta$-induced toxicity. However, the effects of $\mathrm{A} \beta$-targeting molecules on other cellular processes, including those that modulate synaptic plasticity, remain unknown. We report here that $\mathrm{BTA}-\mathrm{EG}_{4}$ decreases $\mathrm{A} \beta$ levels, alters cell surface expression of amyloid precursor protein (APP), and improves memory in wild-type mice. Interestingly, the BTA-EG -mediated $^{-}$ behavioral improvement is not correlated with LTP, but with increased spinogenesis. The higher dendritic spine density reflects an increase in the number of functional synapses as determined by increased miniature EPSC (mEPSC) frequency without changes in presynaptic parameters or postsynaptic $\mathrm{mEPSC}$ amplitude. Additionally, $\mathrm{BTA}_{\mathrm{E}} \mathrm{EG}_{4}$ requires APP to regulate dendritic spine density

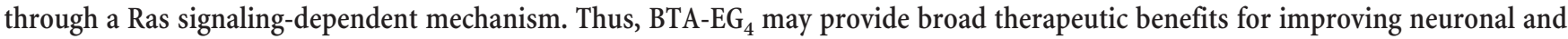
cognitive function, and may have implications in neurodegenerative disease therapy.

\section{Introduction}

Alzheimer's disease $(\mathrm{AD})$ is a neurodegenerative disease characterized by aggregated extracellular amyloid- $\beta(\mathrm{A} \beta)$ plaques in the brain (Finder and Glockshuber, 2007). Extracellular A $\beta$ deposition deteriorates axons, reduces dendritic spine density, and increases oxidative stress (Subbarao et al., 1990), partially by direct interaction between cellular enzymes and $\mathrm{A} \beta$ (Lustbader et al., 2004; Habib et al., 2010). Current therapies for AD, such as acetyl cholinesterase inhibitors and NMDA receptor antagonists (memantine), provide only temporary symptomatic relief without altering the long-term progression of the disease. Other leading strategies seek to alter long-term disease progression, but are severely limited by their induction of widespread toxicity. While

\section{Received April 2, 2012; revised April 16, 2013; accepted April 16, 2013.}

Author contributions: A.M., A.M.D., R.S.T., A.K., J.Y., D.T.S.P., H.-K.L., and H.-S.H. designed research; A.M., T.L., A.M.D., J.M.S., M.H.S., M.R., L.K.H., C.C.C., M.M., A.K., J.Y., H.-K.L., and H.-S.H. performed research; R.S.T., A.K., D.T.S.P., H.-K.L., and H.-S.H. contributed unpublished reagents/analytic tools; A.M., T.L., A.M.D., J.M.S., M.H.S., M.R., L.K.H., C.C., M.M., A.K., J.Y., and H.-K.L. analyzed data; A.M., T.L., A.M.D., M.H.S., J.Y., D.T.S.P., H.-K.L., and H.-S.H. wrote the paper.

This work was supported by National Institutes of Health (NIH) Grant AG039708 (H.-S.H.), Establishment and Operation of Korea Brain Research Institute Basic Research Program of the Ministry of Science, ICT and Future Planning (2031-415, H.S.H.), University of California, San Diego, Alzheimer's Disease Research Center NIH Grant $3 P 50$ AG005131 (J.Y.), Wallace H. Coulter Foundation (M.M., R.S.T., J.Y.), and NIH Grant R01-AG034606 (A.K.). We appreciate the generosity of Music for the Mind (M4M) in funding this project (H.S.H.). The monoclonal antibody PSD-95, NR1, and NR2B were developed and obtained from University of California, Davis/NIH NeuroMab Facility.

*A.M. and T.L. contributed equally to this work.

The authors declare no competing financial interests.

Correspondence should be addressed to Dr. Hyang-Sook Hoe, Departments of Neurology and Neuroscience, Georgetown University, 3970 Reservoir Road, NW, Washington, DC 20057-1464. E-mail: hh69@georgetown.edu. DOI:10.1523/JNEUROSCI.1615-12.2013

Copyright $\odot 2013$ the authors $\quad 0270-6474 / 13 / 339306-13 \$ 15.00 / 0$ patients receiving $\mathrm{A} \beta$ immunotherapy showed an apparent reduction in $\mathrm{A} \beta$ plaque load and slowed cognitive decline, adverse side effects of the treatment have included vasogenic edema (Nicoll et al., 2003; Orgogozo et al., 2003). Likewise, while $\gamma$-secretase inhibitors can effectively decrease A $\beta$ peptide levels and improve memory in a mouse model of $\mathrm{AD}$, widespread inhibition of Notch-mediated signaling following treatment results in developmental defects (Loane et al., 2009). Clearly, novel strategies must be developed in parallel both to treat the underlying pathology of the disease and to prevent the adverse side effects of current therapies.

One novel strategy to overcome AD pathology is the use of small molecules to prevent aggregated $\mathrm{A} \beta$ from interacting with cellular components in harmful ways (Selkoe, 2011). Members of the benzothiazole aniline (BTA) family of compounds are characterized as a class of small molecules that have shown great promise in preventing $\mathrm{A} \beta$-protein interactions. Yang et al. previously reported that a tetra-ethylene glycol derivative of BTA (BTA-EG ${ }_{4}$ ) inhibits $\mathrm{A} \beta$-induced cellular damage by surrounding aggregated $\mathrm{A} \beta$ with a bioresistive coating, preventing its association with cellular proteins (Inbar et al., 2006; Habib et al., 2010;

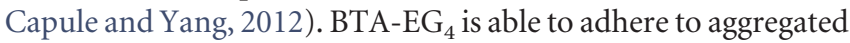
forms of $\mathrm{A} \beta$ with high affinity ( $20 \mathrm{nM})$, cross the blood-brain barrier, and has adequate solubility in aqueous solutions (Inbar et

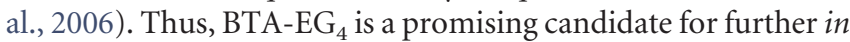
vivo study. While the effects of BTA compounds on AD pathogenesis are areas of active investigation, it is also pertinent to understand their effects on normal brain activity and synaptic function. 
In the present study, we investigated the biological effects of BTA-EG $\mathrm{E}_{4}$ on synaptic function in vitro and in vivo. We initially

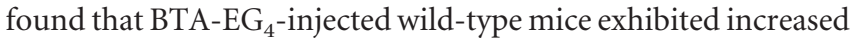
dendritic spine formation, as well as improved memory. The

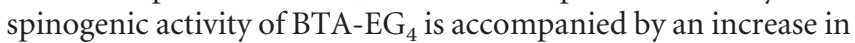
the number of functional synapses, as evidenced by an elevated frequency of AMPA receptor-mediated miniature EPSCs (mEP$\mathrm{SCs}$ ). Furthermore, BTA-EG ${ }_{4}$ acts via amyloid precursor protein (APP) to increase Ras activity as well as downstream Ras signaling, which is necessary for its ability to increase dendritic spine density. These data suggest that $\mathrm{BTA}-\mathrm{EG}_{4}$ may be beneficial as a therapeutic treatment for the neuronal and cognitive dysfunction seen in $\mathrm{AD}$ by targeting Ras-dependent spinogenesis.

\section{Materials and Methods}

Synthesis of 2-(2-(2-(2-hydroxyethoxy)ethoxy)ethoxy)ethyl toluenesulfonate. In a clean, dry $1 \mathrm{~L}$ round-bottom flask equipped with a stirbar, tetra-ethylene glycol $(10.0 \mathrm{~g}, 51.5 \mathrm{mmol})$ was dissolved in $500 \mathrm{ml}$ dry dichloromethane (DCM) and stirred at room temperature. After $5 \mathrm{~min}$, potassium iodide (1.71 g, $10.3 \mathrm{mmol}), \mathrm{Ag}_{2} \mathrm{O}$ (17.9 g, $\left.77.2 \mathrm{mmol}\right)$, and p-toluenesulfonyl chloride $(10.8 \mathrm{~g}, 56.6 \mathrm{mmol})$ were successively added to the reaction flask. The reaction mixture was stirred vigorously for $2 \mathrm{~h}$, filtered through Celite to remove the solids and concentrated in vacuo. The residue was purified via silica column chromatography (100\% DCM to $95: 5 \mathrm{DCM} / \mathrm{CH}_{3} \mathrm{OH}$ ) giving 2-(2-(2-(2-hydroxyethoxy)ethoxy)ethoxy) ethyl toluenesulfonate as a colorless oil $(13.2 \mathrm{~g}, 74 \%):{ }^{1} \mathrm{H}-\mathrm{NMR}(400$ $\left.\mathrm{MHz}, \mathrm{CDCl}_{3}\right): \delta=7.74(\mathrm{~d}, 8.0 \mathrm{~Hz}, 2 \mathrm{H}), 7.30(\mathrm{~d}, 8.0 \mathrm{~Hz}, 2 \mathrm{H}), 4.11(\mathrm{t}, 4.8$ $\mathrm{Hz}, 2 \mathrm{H}), 3.66-3.53(\mathrm{~m}, 12 \mathrm{H}), 2.79(\mathrm{~s}, 1 \mathrm{H}), 2.39(\mathrm{~s}, 3 \mathrm{H}) ;{ }^{13} \mathrm{C}-\mathrm{NMR}(100$ $\mathrm{MHz}, \mathrm{CDCl}_{3}$ ); $\delta=145.04,133.17,130.10$ (2C), 128.19 (2C), 70.95, $70.79,70.70,69.49,68.88,21.87$. Electrospray ionization tandem mass spectrometry (ESI-MS) [mass-to-charge ratio $(\mathrm{m} / \mathrm{z})$ ] was calculated for $\mathrm{C}_{15} \mathrm{H}_{24} \mathrm{O}_{7} \mathrm{~S}[\mathrm{M}]^{+}$value of 348.1243 ; found values were $[\mathrm{M}+\mathrm{H}]^{+}$ 348.96, $\left[\mathrm{M}+\mathrm{NH}_{4}\right]^{+} 365.94$, and $[\mathrm{M}+\mathrm{Na}]^{+} 371.08$.

Synthesis of 2-(2-(2-(2-iodoethoxy)ethoxy)ethoxy)ethanol. 2-(2-(2-(2Hydroxyethoxy)ethoxy)ethoxy)ethyl toluenesulfonate (12.01 g, 34.5 $\mathrm{mmol}$ ), sodium iodide (20.7 g, $137.9 \mathrm{mmol})$, and $200 \mathrm{ml}$ of dry acetone were combined in a clean, dry, round-bottom flask and heated to reflux with vigorous stirring. After $12 \mathrm{~h}$, the reaction was cooled to room temperature and diluted with $100 \mathrm{ml}$ of ethyl acetate. The organic phase was washed with $10 \% \mathrm{Na}_{2} \mathrm{~S}_{2} \mathrm{O}_{3}(2 \times 10 \mathrm{ml})$, deionized $\mathrm{H}_{2} \mathrm{O}(1 \times 20 \mathrm{ml})$, and saturated $\mathrm{NaCl}(1 \times 20 \mathrm{ml})$; dried over anhydrous $\mathrm{Na}_{2} \mathrm{SO}_{4}$; filtered; and concentrated in vacuo giving 2-(2-(2-(2-iodoethoxy)ethoxy)ethoxy) ethanol as a pale yellow oil $(5.61 \mathrm{~g}, 54 \%):{ }^{1} \mathrm{H}-\mathrm{NMR}\left(400 \mathrm{MHz}, \mathrm{CDCl}_{3}\right)$, $\delta=3.73-3.58(\mathrm{~m}, 14 \mathrm{H}), 3.24(\mathrm{t}, 2 \mathrm{H}), 2.59(\mathrm{~s}, 1 \mathrm{H}) ;{ }^{13} \mathrm{C}-\mathrm{NMR}(100 \mathrm{MHz}$, $\left.\mathrm{CDCl}_{3}\right), \delta=72.70,72.19,70.90,70.76,70.58,70.39,61.94,3.07$.

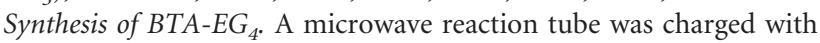
2-(2-(2-(2-iodoethoxy)ethoxy)ethoxy)ethanol ( $1.47 \mathrm{~g}, 4.83 \mathrm{mmol})$, benzothiazole aniline $(3.49 \mathrm{~g}, 14.5 \mathrm{mmol})$, potassium carbonate $(3.34 \mathrm{~g}, 24.2$ $\mathrm{mmol}$ ), and $20 \mathrm{ml}$ of dry tetrahydrofuran (THF). The tube was then equipped with a small stirbar, sealed, and placed in a microwave reactor. The reaction was heated at $125^{\circ} \mathrm{C}$ for $2 \mathrm{~h}$. The reaction was cooled to room temperature and filtered to remove the solids. The solids washed several times with DCM until the filtrate was colorless. The combined organic layers were concentrated in vacuo and purified by column chro-

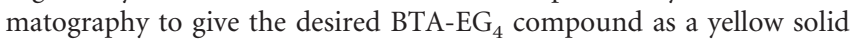
(1.13 g, 56\%): ${ }^{1} \mathrm{H}-\mathrm{NMR}\left(400 \mathrm{MHz}, \mathrm{CDCl}_{3}\right), \delta=7.87$ (d, $\left.8.8 \mathrm{~Hz}, 2 \mathrm{H}\right)$, $7.83(\mathrm{~d}, 8.4 \mathrm{~Hz}, 1 \mathrm{H}) 7.63(\mathrm{~s}, 1 \mathrm{H}) 7.23(\mathrm{~d}, 8.4 \mathrm{~Hz}, 1 \mathrm{H}), 6.68(\mathrm{~d}, 8.8 \mathrm{~Hz}, 2 \mathrm{H})$, 3.76-3.64 (m, 14H), $3.37(\mathrm{t}, 5.2 \mathrm{~Hz}, 2 \mathrm{H}), 2.47(\mathrm{~s}, 3 \mathrm{H}) ;{ }^{13} \mathrm{C}-\mathrm{NMR}(100$ $\left.\mathrm{MHz}, \mathrm{CDCl}_{3}\right), \delta=168.03,152.64,150.92,134.87,134.47,129.13$ (2C), $127.70,122.88,122.03,121.41,112.82$ (2C), 72.86, 70.88, 70.69, 70.43 (2C), 69.64, 61.91, 43.32, 21.70. HR-ESI-MS $(\mathrm{m} / \mathrm{z})$ calculated for a $\mathrm{C}_{22} \mathrm{H}_{28} \mathrm{~N}_{2} \mathrm{O}_{4} \mathrm{SNa}[\mathrm{M}+\mathrm{Na}]$ value of 439.1662 ; the found value for $[\mathrm{M}+\mathrm{Na}]^{+}$was 439.1660 .

Cerebrovascular permeability and pharmacokinetic analysis of BTA-EG in wild-type mice. The partitioning of $\mathrm{BTA}-\mathrm{EG}_{4}$ between plasma and brain was studied in male CD-1 mice. The mice were dosed with 10

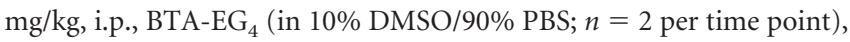

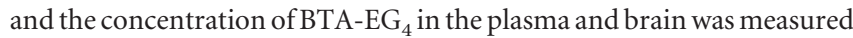
over time. Blood was collected via cardiac puncture and was pooled in EDTA tubes and centrifuged, and the plasma was isolated. The brain was collected from each mouse, snap frozen, and homogenized in $2 \mathrm{ml}$ of PBS. The concentration of BTA-EG ${ }_{4}$ in the plasma and brain at each time point was determined by liquid chromatography/MS/MS, and the concentrations of BTA-EG $\mathrm{BG}_{4}$ in the plasma and brain were plotted as a function of time. The following pharmacokinetic parameters for the plasma and brain profile of BTA-EG $\mathrm{EG}_{4}$ were also calculated: the half-life $\left(t_{1 / 2}\right)$ for BTA-EG ${ }_{4}$ in the plasma and brain, the maximum concentration $\left(\mathrm{C}_{\max }\right)$ of BTA-EG 4 in the plasma and brain, the area under the concentrationtime curve (AUC), the brain-to-plasma ratio (BB), and the logarithmic brain-to-plasma ratio ( $\log \mathrm{BB})$.

Cell lines. COS7 cells (Lombardi Co-Resources Cancer Center, Georgetown University) were maintained in Opti-MEM (Invitrogen) with $10 \%$ fetal bovine serum (FBS; Life Technologies) in a $5 \% \mathrm{CO}_{2}$ incubator. The cells were transiently transfected with $0.5-1 \mu$ g of plasmid in FuGENE 6 (Roche) according to the manufacturer's protocol and cultured for $24 \mathrm{~h}$ in DMEM containing 10\% FBS. For cotransfections, cells were similarly transfected with $0.5-1 \mu \mathrm{g}$ of each plasmid in FuGENE 6 (Roche) and cultured for $24 \mathrm{~h}$ in DMEM with $10 \%$ FBS.

Primary neuron culture and immunostaining. Primary hippocampal neurons from E19 Sprague Dawley rats were cultured at $150 \mathrm{cells} / \mathrm{mm}^{2}$, as previously described (Pak et al., 2001). Neurons were transfected using Lipofectamine 2000 (Invitrogen) or calcium phosphate precipitation with GFP + poly-L-lysine (PLL), GFP + APP shRNA, or GFP + APP and treated with $\mathrm{BTA}^{-\mathrm{EG}_{4}}$. The following antibodies were used: mouse antiGFP (9F9.F9, Novus Biologicals), rabbit anti-GFP (A11122, Invitrogen), rabbit anti-GluR1 (PC246, Calbiochem), mouse anti-GluR2 (556341, BD Pharmingen, BD Biosciences), mouse anti-postsynaptic density-95 (PSD-95) (NeuroMabs), mouse anti-synaptophysin (s5768, Sigma Aldrich), rabbit APP N terminal (A8967, Sigma-Aldrich), anti-Ras (610001, BD Biosciences), anti-RasGRF1 (C-20, Santa Cruz Biotechnology; 610149, BD Biosciences), anti-ERK1/2 (4695, Cell Signaling Technology), anti-p-ERK1/2 (36880, Invitrogen), anti-CREB (D76D11, Cell Signaling Technology), anti-p-CREB (06-519, Millipore), and mouse anti-c-Myc (9E10, Novus Biologicals). Cultured hippocampal neuron images were acquired by LSM 510 laser scanning confocal microscope (Zeiss). Confocal $z$-series image stacks encompassing entire dendrite segments were analyzed using MetaMorph software (Universal Imaging). We transfected cells with GFP to visualize dendrites and dendritic spines, followed by immunostaining with synaptophysin or PSD-95. Using MetaMorph software, we measured the average puncta number along dendritic segments.

GST pull-down assay. To measure levels of active Ras, brain lysate homogenized with Ral buffer ( $25 \mathrm{~mm}$ Tris- $\mathrm{HCl}, \mathrm{pH} 7.4,250 \mathrm{~mm} \mathrm{NaCl}$, $0.5 \% \mathrm{NP} 40,1.25 \mathrm{~mm} \mathrm{MgCl}_{2}$, and 5\% glycerol) from APP transgenic, APP knock-out (KO), or wild-type mice was incubated with GST-Raf-RBD purified protein coupled with glutathione Sepharose (GE Healthcare) overnight at $4^{\circ} \mathrm{C}$. After $24 \mathrm{~h}$, pellets were washed with Ral buffer and Western blotting was conducted with anti-Ras.

Cell surface biotinylation. COS7 cells were transiently transfected with APP for $24 \mathrm{~h}$ in Opti-MEM containing 10\% fetal bovine serum, and then treated with BTA-EG 4 or control (CTRL) for $24 \mathrm{~h}$. After $24 \mathrm{~h}$, surface proteins were biotin labeled, immobilized with NeutrAvidin TM Gel and incubated $1 \mathrm{~h}$ with SDS-PAGE sample buffer, including $50 \mathrm{~mm}$ DTT, as described previously (Minami et al., 2010). Elutes were analyzed for APP by immunoblotting.

Live cell surface immunostaining. Immunostaining of surface APP in hippocampal neurons was performed as described previously (Hoe et al., 2012). Briefly, live neurons were incubated with APP antibodies (10 $\mu \mathrm{g} / \mathrm{ml}$ in conditioned medium) for $10 \mathrm{~min}$, and then briefly fixed in $4 \%$ paraformaldehyde (nonpermeabilizing conditions). Surface-labeled APP was detected with Alexa Fluor-555 secondary antibodies. Cells were then permeabilized in methanol $\left(-20^{\circ} \mathrm{C}, 90 \mathrm{~s}\right)$, and incubated with antiGFP antibody to identify transfected neurons.

Animals. Wild-type C57BL/6J and APP knock-out mice (B6.129S7$\mathrm{APP}^{\mathrm{tm} 1 \mathrm{Dbo} / \mathrm{J})}$ were obtained from Jackson Laboratories. CD1 mice were obtained from Vivasource. All animal experiments were approved by the 
A

Wild-type mice BTA-EG 4 (10 mg/kg)

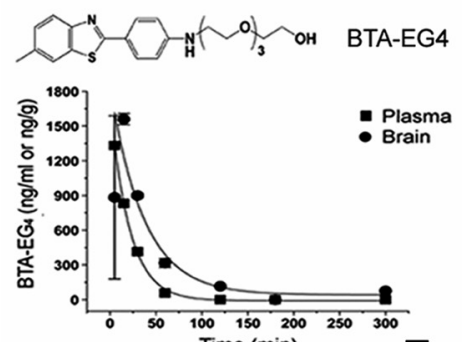

D Wild-type mice

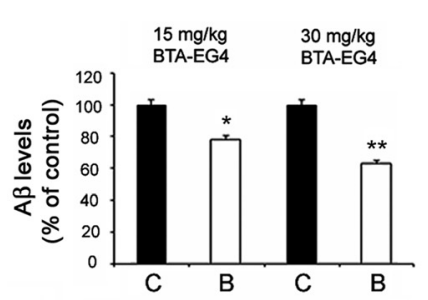

H

COS7 cells



I

Primary cortical neurons

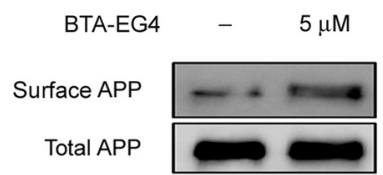

B

\begin{tabular}{lc}
\hline Pharmacokinetic parameters & Value \\
\hline $\mathrm{t}_{1 / 2 \text { plasma }(\mathrm{min})}$ & 14 \\
$\mathrm{t}_{1 / 2}$ brain $(\mathrm{min})$ & 27 \\
$C_{\text {max plasma }(\mathrm{ng} / \mathrm{ml})}$ & 1300 \\
C max brain $(\mathrm{ng} / \mathrm{g})$ & $1600 \pm 48$ \\
AUC plasma & 26000 \\
AUC brain & 69600 \\
Brain:Plasma ratio (BB) & 2.68 \\
Log (BB) & 0.43 \\
\hline
\end{tabular}

F WT mice

\begin{tabular}{llllll}
$\mathrm{KDa}$ & $\mathrm{C}$ & $\mathrm{B}$ & $\mathrm{C}$ & $\mathrm{B}$ \\
\hline
\end{tabular}

KDa C



$42=-\ldots$-actin

$\mathrm{KDa} \quad \mathrm{C} \quad \mathrm{B} \quad \mathrm{C} \quad \mathrm{B}$

$100 \leadsto$ SAPP

$42=-2$-actin



C Primary cortical neurons

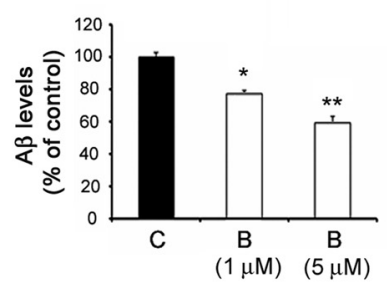

G

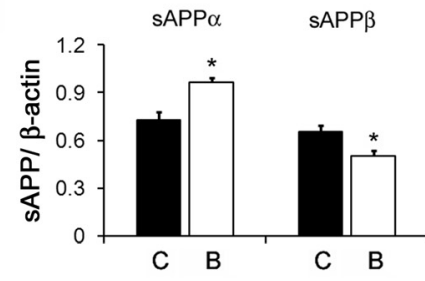

J Primary hippocampal neurons

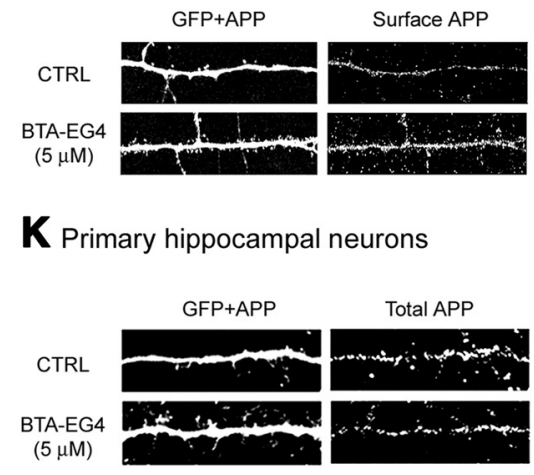

$\mathbf{L}$

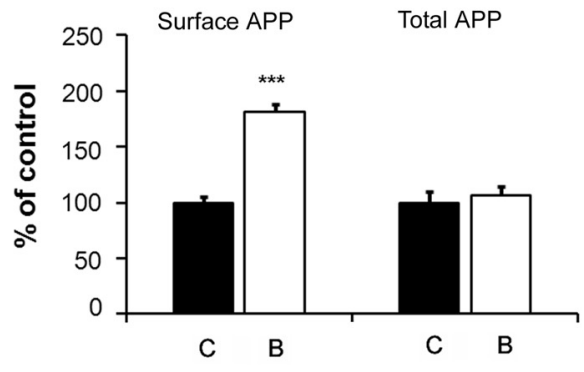

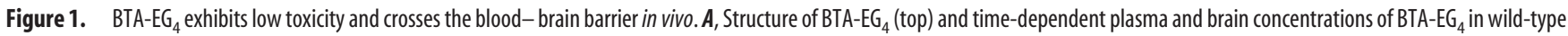
mice that were injected ( $10 \mathrm{mg} / \mathrm{kg}$, i.p.; $n=2$ per time point). $\boldsymbol{B}$, Table summarizing the calculated pharmacokinetic parameters for the plasma and brain profile of $B T_{A}-E_{4}$. Parameters include the $t_{1 / 2}$ for $\mathrm{BTA}_{\mathrm{A}} \mathrm{EG}_{4}$ in the plasma and brain, the $\mathrm{C}_{\max }$ of $\mathrm{BTA}-\mathrm{EG}_{4}$ in the plasma and brain, the $\mathrm{AUC}$, the $\mathrm{BB}$, and the $\mathrm{Log} \mathrm{BB}$. C, Primary cortical neuronal cells were treated with control, or 1 or $5 \mu \mathrm{MBTA}-\mathrm{EG}_{4}$ for $24 \mathrm{~h}$. A $\beta$ levels in the conditioned media were determined by ELISA ( $n=12 /$ group). D, Wild-type mice were injected with $15 \mathrm{mg} / \mathrm{kg}$, i.p., BTA-EG ${ }_{4}$ or $30 \mathrm{mg} / \mathrm{kg} \mathrm{BTA-EG}_{4}$ daily for 2 weeks, and A $\beta$ levels were measured in the brain ( $n=12 /$ group). $E$, $\boldsymbol{F}$, Wild-type mice were injected with $30 \mathrm{mg} / \mathrm{kg} \mathrm{BTA-EG}$ for 2 weeks and sAPP $\alpha$, sAPP $\beta$, full-length APP, APP C-terminal fragment (CTF), and $\beta$-actin were measured $(n=3)$. G, Quantification of SAPP $\alpha$ and sAPP $\beta$ from $\boldsymbol{E}$ and $\boldsymbol{F}(n=3 /$ group). The sAPP $\alpha$ and sAPP $\beta$ signals for each sample were normalized to $\beta$-actin. $\boldsymbol{H}, \boldsymbol{I}$, COS7 cells expressing APP $(\boldsymbol{H}, n=3)$ or primary cortical neurons $(\boldsymbol{I}, n=3)$ were treated with $\mathrm{BTA}^{-\mathrm{EG}_{4}}(5 \mu \mathrm{m})$ for $24 \mathrm{~h}$. Cell surface proteins were biotinylated, isolated with avidin-conjugated beads, and immunoblotted with $6 \mathrm{E} 10$ or $22 \mathrm{C} 11$ antibody. J, Cultured hippocampal neurons (DIV18) were transfected with GFP and APP and treated with BTA-EG for $24 \mathrm{~h}$, and live cell surface staining was conducted. Left panels, GFP; right panels, surface APP ( $n=10$ /group). $\boldsymbol{K}$, Cultured hippocampal neurons (DIV18) were transfected with GFP and APP, treated with BTA-EG ${ }_{4}$ for 24 h, and immunostained with anti-APP. Left panels, GFP; right panels, total APP ( $n=10 /$ group). L, Quantification of surface APP intensity from Jand total APP from $K .{ }^{*} p<0.05,{ }^{* *} p<0.01$, ${ }^{* * *} p<0.001$. C, Control; B, BTA-EG4.

Institutional Animal Care and Use Committees at Georgetown University and Johns Hopkins University. All animals were maintained according to protocols approved by the Animal Welfare and Use Committee at both institutions.

Golgi staining and morphological analysis of dendritic spines. To analyze dendritic spine density and morphology in the brain, FD Rapid GolgiStain Kit (FD NeuroTechnologies) was used. Dissected mouse brains were immersed in Solution A and B for 2 weeks in dark conditions at room temperature and transferred into Solution $\mathrm{C}$ for $24 \mathrm{~h}$ at $4^{\circ} \mathrm{C}$. Brains were sliced using a VT1000S Vibratome (Leica) at $150 \mu \mathrm{m}$ thickness. Dendritic images were acquired by Axioplan 2 (Zeiss) under bright-field microscopy. Spine width, length, and linear density of cortical layers II/III and CA1 of hippocampus were measured using Scion image software (Scion). Images were coded and dendritic spines were counted in a blinded manner. Spines from 0.2 to $2 \mu \mathrm{m}$ in length were included for analysis. At least 25 apical oblique (AO) and 25 basal shaft (BS) dendrites were measured for spine density from each animal, and these were averaged per animal ( $n=5$ /group). All morphological analysis was performed blind to experimental conditions.

$A \beta E L I S A$. Mouse brains were homogenized in tissue homogenization buffer containing $250 \mathrm{~mm}$ sucrose, $20 \mathrm{~mm}$ Tris base, protease, and phosphatase inhibitors. To measure soluble $\mathrm{A} \beta$, diethylamine (DEA) extraction was performed. Crude $10 \%$ homogenate was mixed with an equal volume of $0.4 \%$ DEA, sonicated, and ultracentrifuged for $1 \mathrm{~h}$ at $100,000 \times g$. The supernatant was collected and neutralized with $10 \%$ $0.5 \mathrm{~m}$ Tris, $\mathrm{pH}$ 6.8. Sensitive and specific ELISAs to rodent A $\beta 1-40$ was purchased from IBL Transatlantic and conducted per the manufacturer's protocol.

Morris water maze. To examine the effects of BTA-EG 4 on cognitive performance, we injected wild-type (B6) mice with BTA-EG ${ }_{4}$ daily for 1 
week, and then began behavior testing. We continued daily injections for another week, for a total treatment course of 2 weeks. The Morris water maze task included training mice to locate a submerged, hidden platform using extramaze visuospatial cues. This system consists of a large, white circular pool with a Plexiglas platform painted white and submerged below the surface of the water, made opaque by the addition of white nontoxic paint. During training, the platform was hidden 14 inches from the side wall in one quadrant of the maze. The animals were gently placed at random into one of the four quadrants, separated by $90^{\circ}$, and facing the wall. The time required (latency) to locate the hidden platform was recorded by a blinded observer and tracked using TOPSCAN, and was limited to $90 \mathrm{~s}$. Animals failing to find the platform within $90 \mathrm{~s}$ were assisted to the platform. Animals were allowed to remain on the platform for $15 \mathrm{~s}$ on the first trial and $10 \mathrm{~s}$ on subsequent trials. Twenty-four hours after the final learning trial, a probe trial of $90 \mathrm{~s}$ was given. We recorded the percentage of time spent in the quadrant where the platform was previously located. As a control experiment, we tested motor impairment or visual discriminative ability. The animals were required to locate a clearly visible black platform (placed in a different location), raised above the water surface, at least $12 \mathrm{~h}$ after the last trial.

Fear conditioning. Before initiating fear-conditioning tests, wild-type mice were injected daily with BTA-EG B $_{4}$ or vehicle for 2 weeks $(n=$ 8 /group). Mice were subsequently trained by exposure to a conditioning box (context) for $3 \mathrm{~min}$ before administering a tone (18 s) and footshock $(2 \mathrm{~s})$, which were repeated twice at $1 \mathrm{~min}$ intervals. We performed the contextual test $24 \mathrm{~h}$ after training by re-exposing the mice to the conditioning context. A measurement of freezing behavior was recorded every minute for $3 \mathrm{~min}$ inside of the conditioning box. The cued test was conducted $3 \mathrm{~h}$ following the contextual test. Following a $3 \mathrm{~min}$ reexposure to the conditioning box, a tone (18 s) was administered and freezing behavior was measured for $1 \mathrm{~min}$.

Electrophysiology. Transverse [for Schaffer collateral (SC) input studies] or horizontal [for temporoammonic (TA) input studies] hippocampal slices (400 $\mu \mathrm{m}$ thick) were prepared from adult mice. Slices were made using ice-cold dissection buffer (in mM: 212.7 sucrose, $2.6 \mathrm{KCl}, 1.23$ $\mathrm{NaH}_{2} \mathrm{PO}_{4}, 10$ dextrose, $3 \mathrm{MgCl}_{2}$ and $1 \mathrm{CaCl}_{2} ; 5 \% \mathrm{CO}_{2} / 95 \% \mathrm{O}_{2}$ ), and recordings were performed in a submersion-type chamber perfused with artificial CSF (ACSF; in mм: $124 \mathrm{NaCl}, 5 \mathrm{KCl}, 1.25 \mathrm{NaH}_{2} \mathrm{PO}_{4}, 26$ $\mathrm{NaHCO}_{3}, 10$ dextrose, $1.5 \mathrm{MgCl}_{2}$, and $2.5 \mathrm{CaCl}_{2} ; 5 \% \mathrm{CO}_{2} / 95 \% \mathrm{O}_{2}, 29.5-$ $30.5^{\circ} \mathrm{C}, 2 \mathrm{ml} / \mathrm{min}$ ). For field potential recordings, synaptic responses were evoked using $0.2 \mathrm{~ms}$ duration pulses delivered through a bipolar glass stimulating electrode at $0.0333 \mathrm{~Hz}$. A train of theta burst stimulation (TBS) consisted of a burst of four pulses at $100 \mathrm{~Hz}$ repeated 10 times at $5 \mathrm{~Hz}$. For $4 \times$ TBS, four trains of TBS were given at $10 \mathrm{~s}$ intertrain intervals. For whole-cell recordings, slices were transferred to a submersion-type recording chamber mounted on a fixed stage of an upright microscope (E600 FN, Nikon) with infrared (IR) oblique illumination. AMPA receptor (AMPAR)-mediated mEPSCs were pharmacologically isolated by adding $1 \mu \mathrm{M}$ tetrodotoxin, $20 \mu \mathrm{M}$ bicuculline, and $100 \mu \mathrm{M} \mathrm{D}, \mathrm{L}-2$-amino-5-phosphonopentanoic acid to ACSF $\left(30 \pm 1{ }^{\circ} \mathrm{C}\right.$, saturated with $95 \% \mathrm{O}_{2}$ and $5 \% \mathrm{CO}_{2}$ ), which was continually perfused at a rate of $2 \mathrm{ml} / \mathrm{min}$. Target cells in CA1 were identified by the pyramidshaped soma. These neurons were patched using a whole-cell patch pipette (tip resistance 3-5M 2 ), which was filled with internal solution (in mM: 120 Cs-methanesulfonate, $5 \mathrm{MgCl}_{2}, 8 \mathrm{NaCl}, 1$ EGTA, 10 HEPES, 2 Mg-ATP, 0.5 Na $\mathrm{NaTP}_{3}$ and 0.001 QX-314; pH 7.3, 280-290 mOsm). Recording was initiated $2-3 \mathrm{~min}$ after break-in, and each cell was recorded for 10-15 min to collect enough mEPSCs for analysis. The Axon patch-clamp amplifier 700B (Molecular Devices) was used for voltageclamp recordings. Cells were held at $-70 \mathrm{mV}$, and the recorded mEPSC data were digitized at $10 \mathrm{kHz}$ with a data acquisition board (National Instruments) and acquired through custom-made programs using the Igor Pro software (WaveMetrics). The MiniAnalysis program (Synaptosoft) was used to analyze the acquired mEPSCs. The threshold for detecting mEPSCs was set at three times the root mean square (RMS) noise. There was no significant difference in the RMS noise across the groups $\left[\mathrm{BTA}-\mathrm{EG}_{4}(30 \mathrm{mg} / \mathrm{kg})=1.6 \pm 0.09(n=7)\right.$, control $=1.6 \pm 0.05$ $(n=8) ; t$ test, $p>0.65]$. Recordings were excluded from analysis if the RMS noise was $<2$, the series resistance was $<25 \mathrm{M} \Omega$, and input resis-
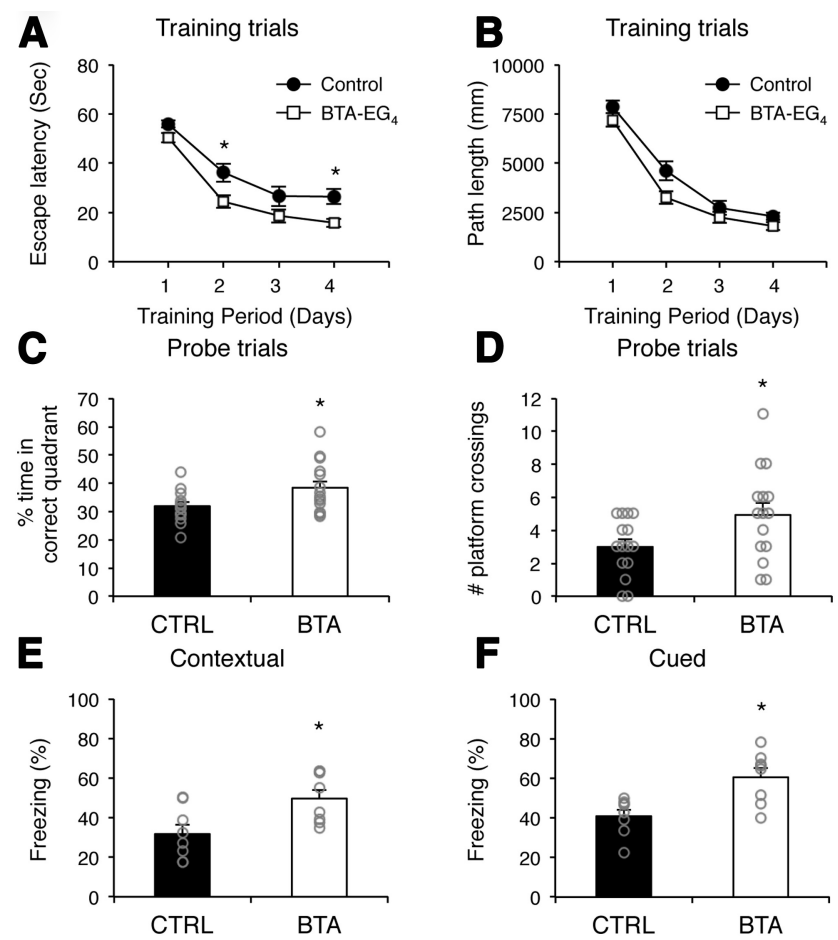

Figure 2. $B T A-E G_{4}$ improves cognitive performance. $A-D$, Spatial learning task for $B T A-E G_{4}$ injected (intraperitoneally) wild-type mice by Morris water maze paradigm. $A$, Escape latencies during the training phase $\left(n=15 ;{ }^{*} p<0.05\right.$ for days 2 and $4 ; p<0.001$ overall). $\boldsymbol{B}$, Path lengths to the platform during training trials (two-way ANOVA, $p=0.6709$ ). $C$, Percentage of time spent in the target quadrant was measured during the probe test on day $5\left({ }^{*} p<0.05\right)$. Individual animal data are shown in gray circles. $\boldsymbol{D}$, Comparison of the number of platform crossings during probe trial on day $5\left(^{*} p<0.05\right)$. Individual animal data are shown in gray circles. $E, F$, Associative learning test for $\mathrm{BTA}_{\mathrm{E}} \mathrm{EG}_{4}$ injected (intraperitoneally) wild-type mice by fear conditioning. $E$, Performance of mice treated with $\mathrm{BTA}_{\mathrm{A}} \mathrm{EG}_{4}(30 \mathrm{mg} / \mathrm{kg})$ daily for 2 weeks before training during the contextual memory test $\left(n=8 /\right.$ group; $\left.{ }^{*} p<0.05\right)$. Individual animal data are shown in gray circles. $F$, Mice were re-exposed to the cue component in a novel context after $24 \mathrm{~h}$, and their behavior was monitored. Mice treated with $\mathrm{BTA}^{-\mathrm{EG}_{4}}$ exhibited significantly enhanced freezing in response to the cue component $\left(n=8 /\right.$ group; $\left.{ }^{*} p<0.05\right)$. Individual animal data are shown in gray circles.

tance was $>100 \mathrm{M} \Omega$. To minimize the impact of dendritic filtering, we adopted the standard approach of excluding mEPSCs with a rise time of $>3 \mathrm{~ms}$, as well as cells showing a negative correlation between mEPSC amplitude and rise time (Rall, 1969). Only $\sim 4 \%$ of the total recorded cells (at most, 1 cell per experimental group) were excluded due to negative correlation between mEPSC rise and amplitude. One hundred consecutive mEPSCs that met the rise-time criteria were analyzed from each cell. AMPAR- and NMDAR-mediated currents were measured at -70 and $+40 \mathrm{mV}$, respectively. AMPAR-mediated EPSC amplitudes were measured at the peak of the current at $-70 \mathrm{mV}$. NMDAR-mediated EPSC amplitudes were measured $100 \mathrm{~ms}$ after the stimulation artifact. Data are the means \pm SE. Student's $t$ test was used for two-group comparisons. For all statistical tests, $p<0.05$ was considered statistically significant.

Slice surface biotinylation. Hippocampal slices (400 $\mu \mathrm{m}$ thick) were prepared as described above. CA3 and DG regions were cut away after the slice preparation to isolate CA1. After $30 \mathrm{~min}$ of recovery at room temperature, the slices were transferred to $30^{\circ} \mathrm{C}$ for an additional $30 \mathrm{~min}$ of recovery. The slices were then transferred to ice-cold ACSF for $10 \mathrm{~min}$, and subsequently to ice-cold ACSF containing $1 \mathrm{mg} / \mathrm{ml}$ biotin (EZ-Link Sulfo-NHS-SS-Biotin, Pierce) saturated with $5 \% \mathrm{CO}_{2} / 95 \% \mathrm{O}_{2}$ for 15 $\mathrm{min}$. The slices were then washed in TBS ( $50 \mathrm{~mm}$ Tris, $0.9 \% \mathrm{NaCl}, \mathrm{pH}$ 7.4) containing $100 \mathrm{~mm}$ glycine 5 times for $1 \mathrm{~min}$ each before homogenized in ice-cold $0.2 \%$ SDS/ $1 \%$ Triton X-100 immunoprecipitation buffer (TX-IPB; $20 \mathrm{~mm} \mathrm{Na}_{3} \mathrm{PO}_{4}, 150 \mathrm{~mm} \mathrm{NaCl}, 10$ mм EDTA, 10 mм EGTA, $10 \mathrm{~mm} \mathrm{Na}_{4} \mathrm{P}_{2} \mathrm{O}_{7}, 50 \mathrm{~mm} \mathrm{NaF}$, and $1 \mathrm{mM} \mathrm{Na}_{3} \mathrm{VO}_{4}, \mathrm{pH}$ 7.4; with $1 \mu \mathrm{M}$ 
A

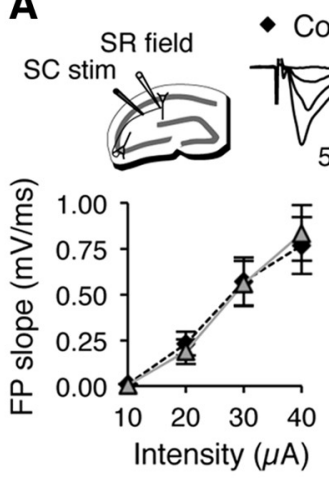

D

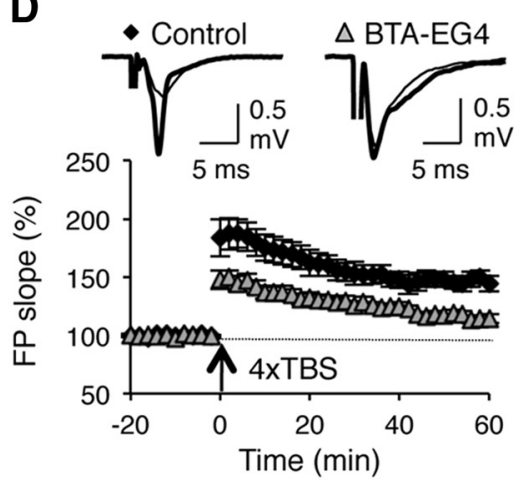

B
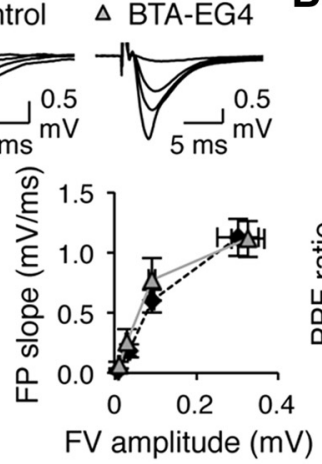

E
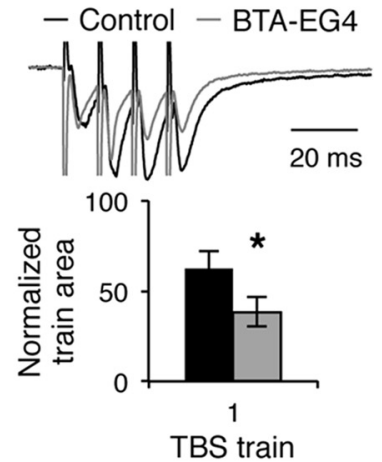

C

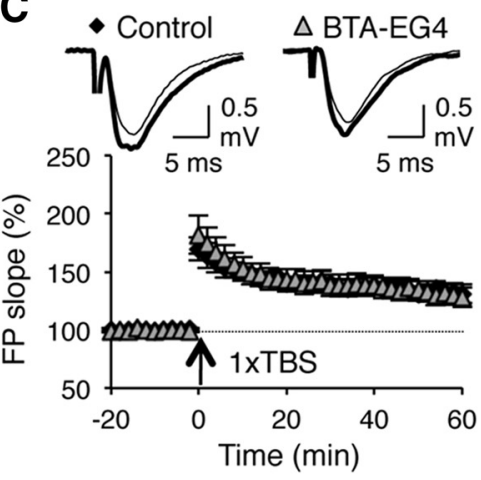

F
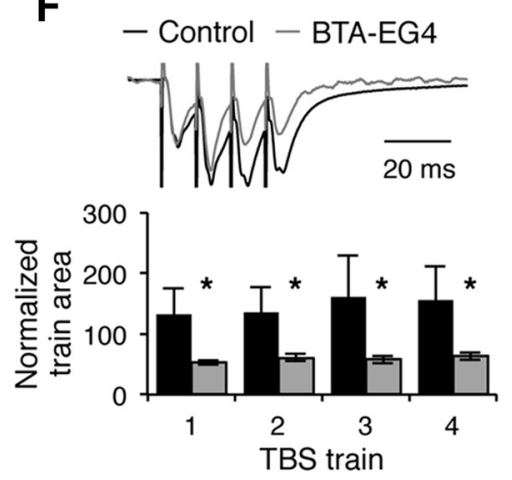



$\triangle$ BTA-EG4

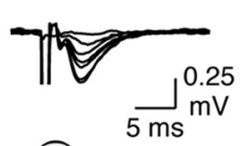


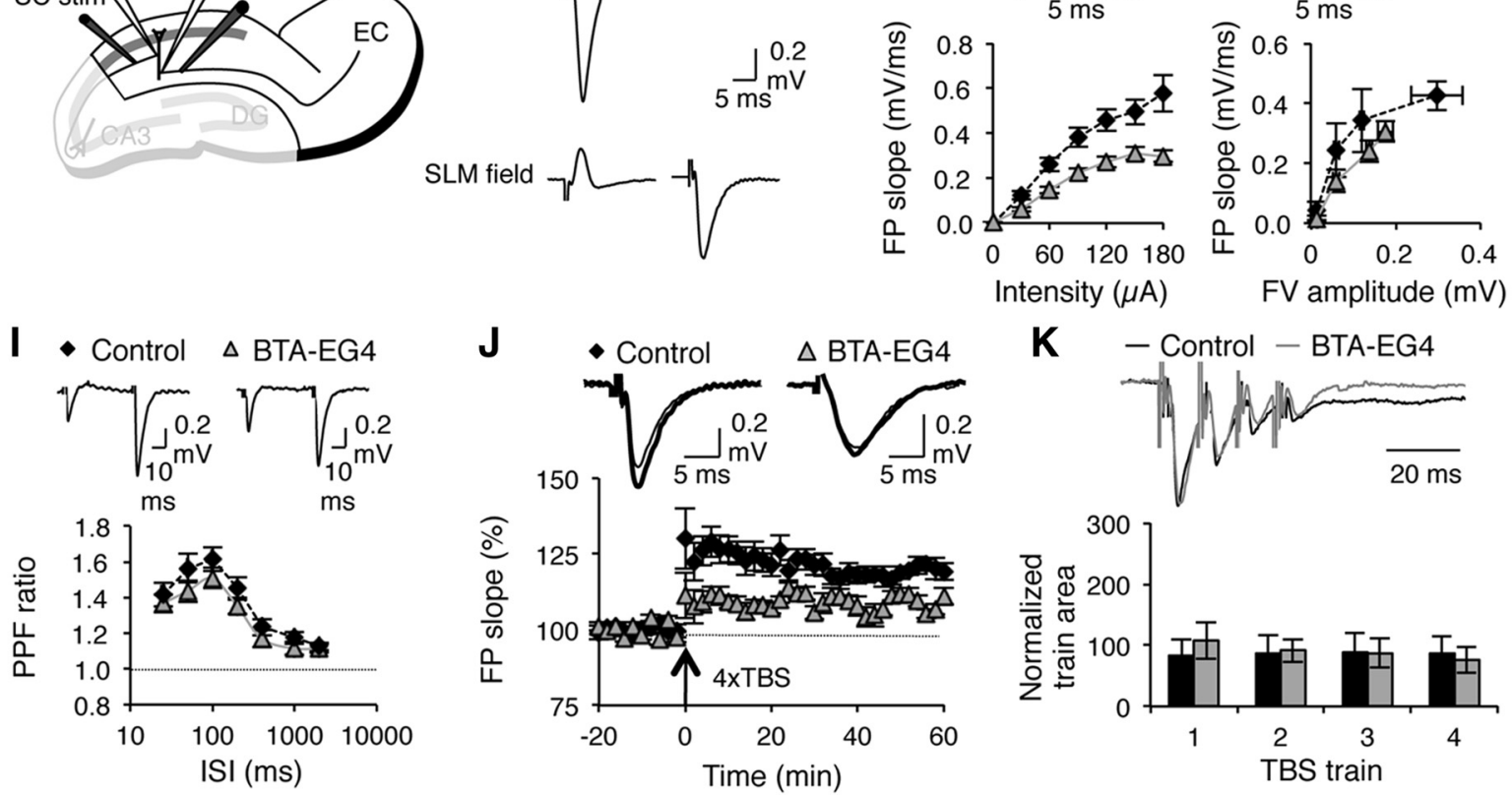

Figure 3. BTA-EG ${ }_{4}$ does not enhance LTP in CA1. A-F, SC inputs to CA1. $\boldsymbol{A}$, No significant difference in input- output function. Left, field potential (FP) slope plotted against stimulation intensity. CTRL: $n=15$ slices, six mice; BTA: $n=18$ slices, six mice. Right, FP slope normalized to fiber volley (FV). Top left, Schematic of recording. Top right, Representative FP traces. $\boldsymbol{B}$, No change in presynaptic function. Top, Representative traces at 50 ms interstimulus interval (ISI). Bottom, paired pulse facilitation (PPF) ratio at different ISI. $\boldsymbol{C}, \boldsymbol{D}$, No difference in the magnitude of LTP induced by $1 \times$ TBS (CTRL: $n=9$ slices, 6 mice, BTA: $n=10$ slices, 5 mice, $t$ test: $p=0.359 ;$ ) and a reduction with $4 \times$ TBS (CTRL: $n=8$ slices, $n=4$ mice, BTA: $n=11$ slices, 6 mice, $t$ test: $p<0.01$; $\boldsymbol{D})$ in the BTA-treated group. Top, Representative traces (baseline: thin line, post-LTP: thick line). $\boldsymbol{E}, \boldsymbol{F}$, Comparison of response integration during $1 \times T B S(\boldsymbol{E})$ and $4 \times$ TBS $(\boldsymbol{F})$. ${ }^{*} p<0.05$. $\boldsymbol{G}-\boldsymbol{K}$, TA inputs to CA1. G, Isolation of TA inputs by stimulating the stratum lucidum-moleculare (SLM). Left, Schematics of recording. Right, Representative FP traces following stimulation of SC inputs by an electrode placed in stratum radiatum (SR) or SLM when recording from SR or SLM. $\boldsymbol{H}$, A reduction in input- output function with stimulation intensity (left), which is normalized when corrected for presynaptic recruitment of axons (right) (CTRL: $n=24$ slices, $n=5$ mice, BTA: $n=23$ slices, $n=5$ mice). Top, Representative traces. I, Normal PPF ratio (CTRL: $n=25$ slices, $n=5$ mice, BTA: $n=$ 22 slices, $n=5$ mice). Top, Representative traces taken at 50 ms ISI. J, Reduced TA-LTP (CTRL: $120 \pm 2.1 \%$ at $1 \mathrm{~h}$ post-LTP, $n=11$ slices, $n=5$ mice; BTA: $109 \pm 1.2 \%, n=10$ slices, $n=4$ mice; $t$ test, $p<0.01)$. $\boldsymbol{K}$, Normal summation of responses during TA-LTP induction protocol. 


\section{Hippocampus CA1 (30 mg/kg BTA-EG4)}
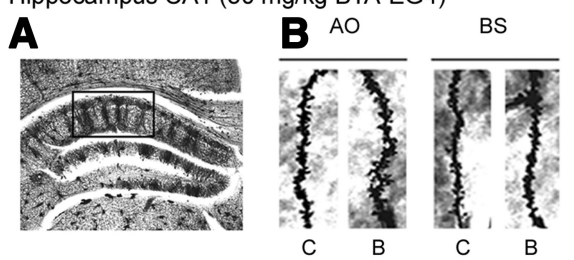

Cortical Layers II/III (30 mg/kg
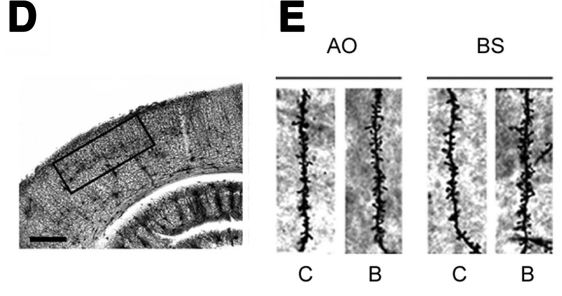

Cortical Layers II/III (30 mg/kg BTA-EG4)

G

CTX Total Width

H
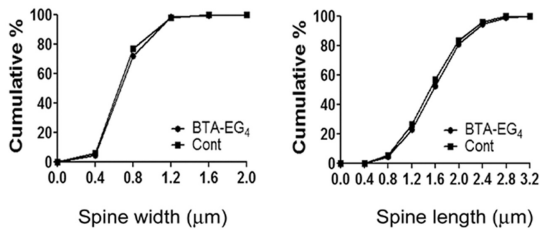

C



$\mathbf{F}$

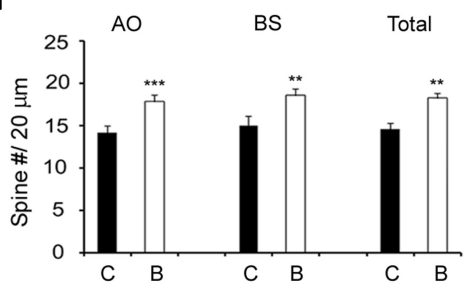

Hippocampus CA1 (30 mg/kg BTA-EG4)



HPC Total Width HPC Total Length

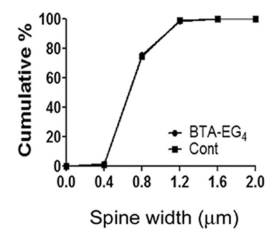

test for multiple comparisons, with significance determined at $p<0.05$. Cumulative distribution plots were analyzed using the Kolmogorov-Smirnov test. Descriptive statistics were calculated with StatView 4.1 and expressed as the mean \pm SEM.

\section{Results}

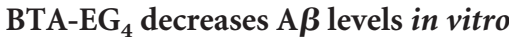
and in vivo

We examined the biological and pharma-

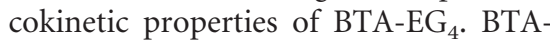
$\mathrm{EG}_{4}$ readily crosses the blood-brain barrier and is rapidly distributed to the brain (Iyer et al., 2002) with an estimated $\log \mathrm{BB}$ value of 0.43 (Fig. $1 A, B$ ). While it is clear from these studies that BTA-EG readily distributes to the brain, we make this conclusion from the analysis of brain and plasma samples of only four mice at each time point (two dosed with BTA-EG and two dosed only with vehicle). The quantitative pharmacokinetic parameter values provided (Fig. 1B) should, therefore, be considered only as estimated values. We further found that daily injections of BTA-EG 4 ( $\leq 50 \mathrm{mg} / \mathrm{kg}$, i.p.) were well tolerated in wild-type mice for $16 \mathrm{~d}$, and necropsy revealed no adverse effects on major organs.

To test whether BTA-EG $\mathrm{E}_{4}$ alters $\mathrm{A} \beta$ production in vitro, primary cortical neu-

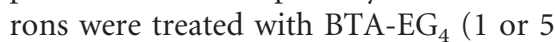
$\mu \mathrm{M})$ or control (10\% DMSO), and $\mathrm{A} \beta$ levels were measured using ELISA. BTA-EG significantly decreased $\mathrm{A} \beta$ protein levels (Fig. 1C). We then examined whether BTA-EG $\mathrm{E}_{4}$ can alter $\mathrm{A} \beta$ levels in vivo by injecting wild-type mice daily for 2 weeks with BTA-EG $_{4}$ (15 or $30 \mathrm{mg} / \mathrm{kg}, 10 \%$

okadaic acid and $10 \mathrm{kIU} / \mathrm{ml}$ aprotinin) by 30 gentle strokes using glassTeflon tissue homogenizers (Pyrex). The homogenates were centrifuged for $10 \mathrm{~min}$ at $13,200 \times \mathrm{g}$, at $4^{\circ} \mathrm{C}$. Protein concentration of the supernatant was normalized to $0.6-1.5 \mathrm{mg} / \mathrm{ml}$. Some of the supernatants were saved as inputs, and the remaining supernatant was mixed with NeutrAvidin slurry $\left(1: 1\right.$ in $1 \%$ TX-IPB) and rotated overnight at $4^{\circ} \mathrm{C}$. The NeutrAvidin beads were isolated by brief centrifugation at $1000 \times g$, and washed $3 \times$ $1 \%$ TX-IPB, $3 \times 1 \%$ TX-IPB plus $500 \mathrm{~mm} \mathrm{NaCl}$, followed by $2 \times 1 \%$ TX-IPB. The biotinylated surface proteins were then eluted from the NeutrAvidin beads by rotating at room temperature for $15 \mathrm{~min}$ in gel sample buffer with $2 \mathrm{~mm}$ DTT. The input (total homogenate) and biotinylated samples (surface fraction) were run on separate gels, and processed for immunoblot analysis using GluA1 (sc-55509, Santa Cruz Biotechnology), GluA2/3 (07-598, Millipore), GluN1 (a gift from Dr. R.L. Huganir, Johns Hopkins University, Baltimore, MD), GluN2A (07632, Millipore), and GluN2B (71-8600, Invitrogen) antibodies. NMDAR subunit blots were developed using enhanced chemifluorescence substrate (ECF substrate, GE Healthcare). AMPAR blots were probed simultaneously with GluR1 and GluR2/3 antibodies followed by second antibodies linked to Cy5 and Cy3. All blots were scanned using Typhoon 9400 (GE Healthcare), and quantified using Image Quant TL software (GE Healthcare). The signal of each sample on a blot was normalized to the average signal from the control group to obtain the percentage of average control values, which were compared across groups using unpaired Student's $t$ test.

Statistical analyses. All data were analyzed with GraphPad Prism 4 software using either a two-tailed $t$ test or ANOVA with Tukey's post hoc
DMSO in saline, i.p.). We found that wild-type mice injected with both doses of BTA-EG 4 had significantly decreased $\mathrm{A} \beta$ peptide levels compared with controls (10\% DMSO, i.p.) (Fig. 1D), suggesting that $\mathrm{BTA}-\mathrm{EG}_{4}$ can also reduce $\mathrm{A} \beta$ production in vivo. Furthermore, BTA-EG $\mathrm{E}_{4}$ altered APP processing in vivo, as monitored by increased sAPP $\alpha$ ( $\alpha$-secretase cleavage product) and decreased sAPP $\beta$ ( $\beta$-secretase cleavage product) levels in BTA$\mathrm{EG}_{4}$ injected wild-type mice (30 mg/kg, i.p) compared with control-injected mice (Fig. $1 E-G$ ). These findings suggest that BTA-EG ${ }_{4}$ promotes the $\alpha$-secretase-mediated metabolism of APP at the expense of the $\beta$-secretase pathway, which may explain the reduction in $\mathrm{A} \beta$.

It is well known that the majority of $\alpha$-secretase activity occurs on the cell surface, while $\beta$ - and $\gamma$-secretase activity occurs primarily in the early and late endosomes (Huse et al., 2000; Reiss et al., 2006). Thus, if APP is present at the cell's surface, it is preferentially cleaved by $\alpha$-secretase, resulting in decreased $\mathrm{A} \beta$ production. Therefore, we examined whether BTA-EG 4 regulates cell surface expression of APP. To test this initially, COS7 cells were transfected with human APP and treated with BTA-EG $4(5 \mu \mathrm{M})$ or control (10\% DMSO) for $24 \mathrm{~h}$. After performing cell surface



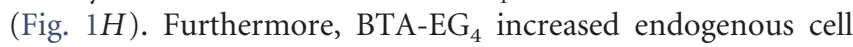


surface APP levels in primary cortical neurons following $24 \mathrm{~h}$ of BTA-EG 4 (5 $\mu \mathrm{M})$ treatment compared with control (10\% DMSO) treatment (Fig. 1I). In an alternative approach to examine the effect of BTA-EG ${ }_{4}$ on cell surface APP expression, we conducted live cell-surface immunostaining in primary hippocampal

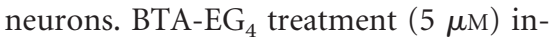
creased cell surface levels of APP relative to vehicle control without affecting total levels of APP (Fig. 1J-L). These results suggest that $B T A-E_{4}$ may reduce $A \beta$ production by increasing the amount of APP present at the cell surface.

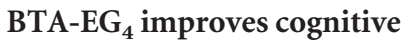
performance in the absence of enhanced long-term potentiation

Several studies have shown that $\mathrm{A} \beta$ accumulation contributes to cognitive deficits (Chang et al., 2011; Chételat et al., 2012). Since we observed that BTA-EG 4 decreases $\mathrm{A} \beta$ levels both in vitro and in vivo (Fig. $1 C, D$ ), we then examined whether BTA-EG ${ }_{4}$ affects learning and memory.

The Morris water maze task was used to assess cognitive performance in wildtype mice injected with BTA-EG ${ }_{4}(30 \mathrm{mg} /$ $\mathrm{kg}$, i.p.) and controls. BTA-EG $\mathrm{E}_{4}$-injected wild-type mice exhibited significantly reduced escape latency during training (Fig. $2 A$ ), which was accompanied by an increase in swim speed $(\mathrm{CTRL}=117 \pm 3.1$ $\mathrm{mm} / \mathrm{s}, \mathrm{BTA}=130 \pm 3.6 \mathrm{~mm} / \mathrm{s} ; p<0.01)$, but no difference in path length to the escape platform (Fig. 2B). These findings suggest that the apparent reduction in escape latency in the BTA$\mathrm{EG}_{4}$ group may simply be a reflection of the effect of the drug on swim speed. The fact that there is no change in the path length to reach the platform, which is a measurement not affected by swim speed, during the training trials suggests that BTA-EG $\mathrm{E}_{4}$ may not improve the learning process. To test whether BTA-EG $\mathrm{B}_{4}$ affects memory, we ran probe trials to measure the percentage of time spent in the correct quadrant and the number of platform cross-

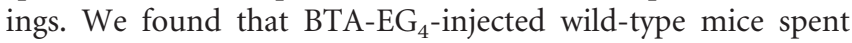
more time in the target quadrant and showed a significantly higher rate of platform crossing during probe trials (Fig. 2C,D),

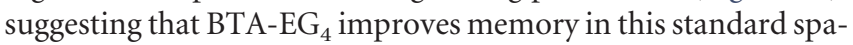
tial memory task.

We also conducted a fear-conditioning paradigm as an alternative method to measure the effect of $B T A-E_{4}$ on cognitive performance. We found that $30 \mathrm{mg} / \mathrm{kg} \mathrm{BTA}-\mathrm{EG}_{4}$-injected wildtype mice showed significantly increased freezing in both the contextual and cued tests (Fig. $2 E, F$ ), suggesting that BTA-EG improves cognitive performance.

Several studies have demonstrated that synaptic plasticity is correlated with learning and memory (Kandel, 2001; VanGuilder et al., 2011). Therefore, we examined whether improved cognitive performance following $\mathrm{BTA}^{-\mathrm{EG}_{4}}$ treatment is associated with altered synaptic function and plasticity. We conducted electrophysiology experiments in an acute hippocampal slice preparation from wild-type mice injected with BTA-EG $430 \mathrm{mg} / \mathrm{kg}$, i.p.) or control solution (10\% DMSO, i.p) for 2 weeks. At the SC inputs to CA1, BTA-EG 4 did not alter basal synaptic transmission or presynaptic function (Fig. $3 A, B$ ). Long-term potentiation (LTP) was either normal or reduced, depending on the induction protocol (Fig. 3C,D). Unexpectedly, the summation of synaptic responses during the LTP induction protocol was reduced (Fig. $3 E, F)$, which suggests that the normal LTP expression is likely due to an upregulation of a downstream signaling cascade. Recent evidence suggests that TA inputs to CA1, rather than SC inputs to CA1, support water maze-type learning (Nakashiba et al., 2008). BTA-EG 4 (30 mg/kg, i.p.) treatment reduced the ability to recruit presynaptic axons per stimulation intensity at TA inputs to CA1 (Fig. 3H, left), but there was no difference in synaptic transmission when responses were normalized to the presynaptic fiber volley amplitude (Fig. $3 H$, right). There was also not a change in presynaptic function (Fig. $3 I$ ). Similar to SC inputs to CA1, LTP at TA inputs also showed a similar reduction in the magnitude of LTP (Fig. $3 J$ ), which occurred in the absence of a change in the response summation during the induction protocol (Fig. $3 \mathrm{~K}$ ). Collectively, these results support the idea that the benefit of BTA-EG $\mathrm{E}_{4}$ to improved cognitive performance is not through enhancing LTP.

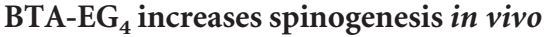

There is precedence that cognitive performance correlates better with dendritic spine density rather than LTP magnitude (Hayashi 
A

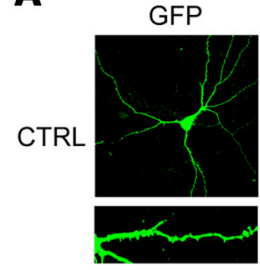

GFP
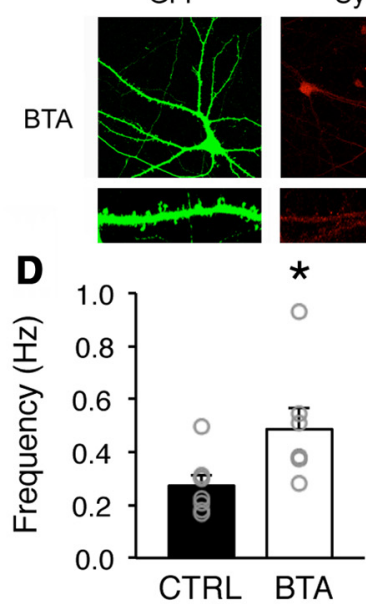

E

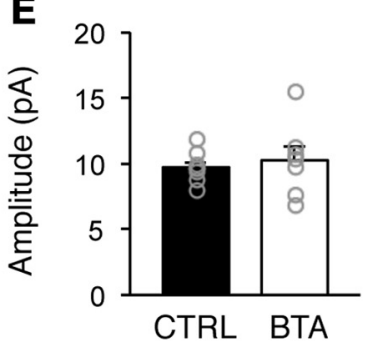

G
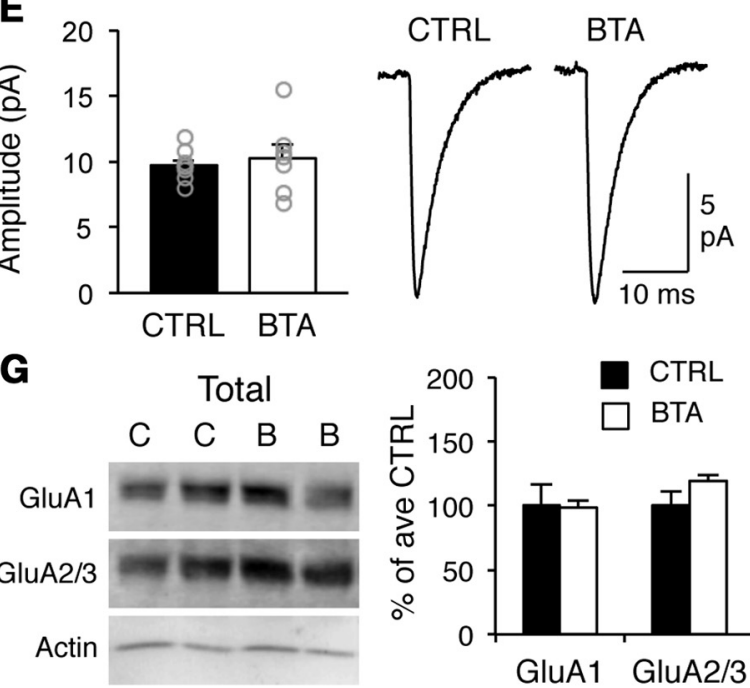

CTRL
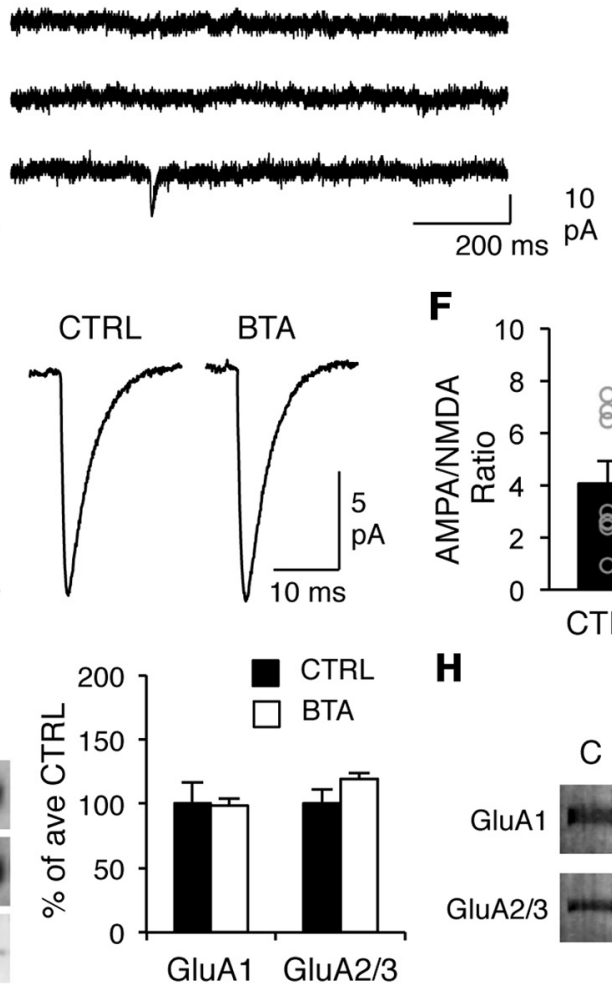

F
C

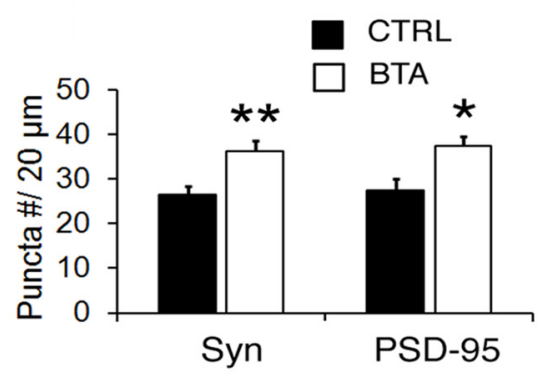

BTA

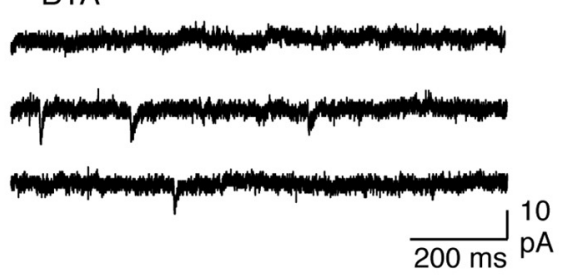

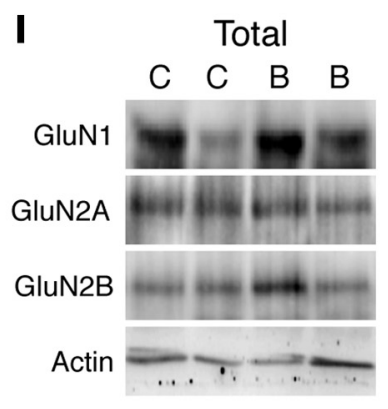

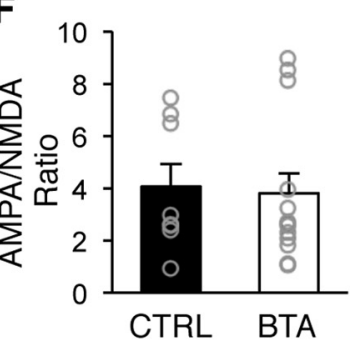

CTRL

BTA
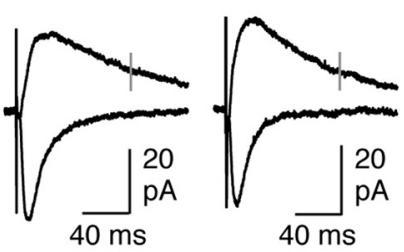

H Surface
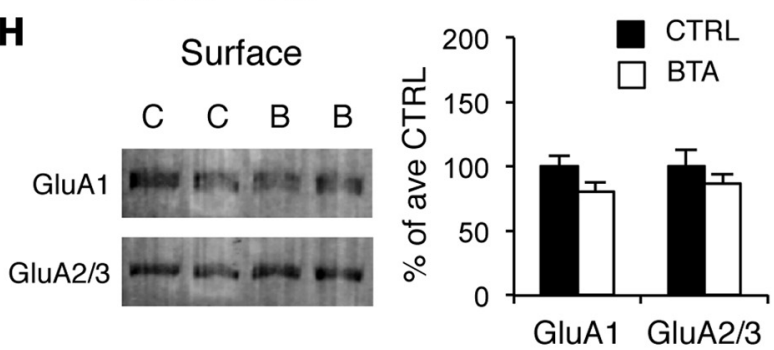

J


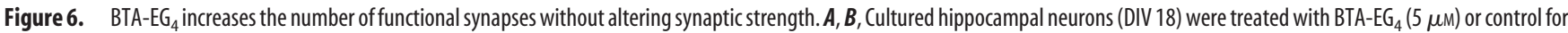
$24 \mathrm{~h}$ and stained for synaptophysin ( $\boldsymbol{A}$, right) and PSD-95 ( $\boldsymbol{B}$, right). Neurons and dendrites were visualized by transfection of GFP ( $\boldsymbol{A}$ and $\boldsymbol{B}$, left panels). $\boldsymbol{C}$, Quantification of average puncta number of synaptophysin and PSD-95 per $20 \mu \mathrm{m}$ length of dendrite $\left(n=10,{ }^{*} p<0.05,{ }^{* *} p<0.01\right) . D, B^{*} A-E_{4}(30 \mathrm{mg} / \mathrm{kg}$, i.p.)-treated mice showed significantly increased mEPSC frequency in CA1 pyramidal neurons. Left, Comparison of average mEPSC frequency (CTRL: $n=7$ cells, 5 mice; BTA: $n=8$ cells, 5 mice; ${ }^{*} t$ test: $\left.p<0.05\right)$. Values for individual cells are shown in gray circles. Right, Representative three consecutive mEPSC traces (1 s each) taken from cells of (TRL and BTA. $\boldsymbol{E}$, No significant change in average mEPSC amplitude ( $n$, the same as in $\boldsymbol{D}$ ). Values for individual cells are shown in gray circles. Right, Average mEPSC trace from each group. $\boldsymbol{F}$, No change in the ratio of AMPA/NMDA-mediated synaptic responses. Values for individual cells are shown in gray circles. Right, Overlap of AMPAR-mediated EPSC measured at $-70 \mathrm{mV}$ and NMDAR-mediated EPSC measured at $+40 \mathrm{mV}$. Dotted line shows where NMDAR responses were measured. $\mathbf{G}-\mathbf{J}$, No change in the total and cell surface levels of $\operatorname{AMPAR}(\boldsymbol{G}, \boldsymbol{H})$ and $\operatorname{NMDAR}(\boldsymbol{I}, \boldsymbol{J})$ subunits in microdissected CA1 slices obtained from control and BTA (30 mg/kg, i.p.)-treated (Figure legend continues.) 
et al., 2004; Morgado-Bernal, 2011). Since we observed that $B$ TA-EG 4 improves memory without enhancing LTP, we hypothesized that BTA-EG 4 promotes cognitive performance by increasing spine density. To test this idea, wild-type mice were injected with BTA-EG 4 (30 mg/kg) or control for 2 weeks. Subsequently, we performed Golgi staining and found that BTA-EG 4 -treated mice showed significantly increased dendritic spine density in the CA1 region of the hippocampus and cortical layers II/III (Fig. 4A-F). However, BTA-EG 4 did not alter spine morphology, including spine head width and spine length, in these areas (Fig. 4G-J). These data suggest that BTA-EG $\mathrm{B}_{4}$ promotes dendritic spine formation without affecting spine morphology.

\section{BTA-EG ${ }_{4}$ requires APP to increase dendritic spine density}

To examine whether BTA-EG 4 acts via APP to increase dendritic spine density, we acutely knocked down APP using shRNA in primary hippocampal neurons. APP shRNA was cotransfected with GFP to visualize dendritic spines, and control cultures were transfected with GFP and PLL (control vector for shRNA construct). We then treated both cultures with $\mathrm{BTA}-\mathrm{EG}_{4}(5 \mu \mathrm{M})$ or vehicle. We found that knockdown of APP on its own showed a trend of a decrease in dendritic spine density and prevented the increase in dendritic spine density with BTA-EG4 treatment (Fig. 5A,B), which suggests that BTA-EG $\mathrm{E}_{4}$ can only increase dendritic spine density in the presence of APP. To confirm this finding in vivo, we examined the effect of BTA-EG 4 on dendritic spine density in APP KO mice. APP KO mice were injected with BTA-EG 4 (30 mg/kg) or vehicle for 2 weeks, and Golgi analysis was conducted on hippocampal CA1 neurons. In APP KOs, we did not find a statistically significant increase in dendritic spine density following BTA-EG $\mathrm{EG}_{4}$ treatment (Fig. 5C,D). This observation suggests that the ability of BTA- $\mathrm{EG}_{4}$ to promote spinogenesis is dependent on APP.
A

B

Primary cortical neurons

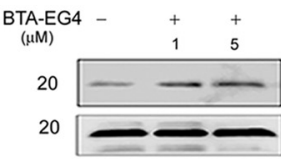

E
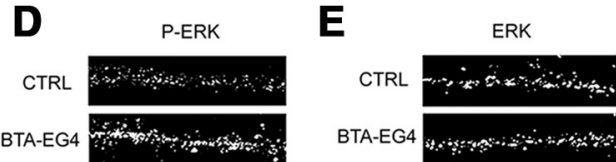

$\mathbf{F}$

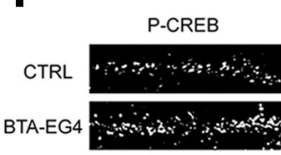

G
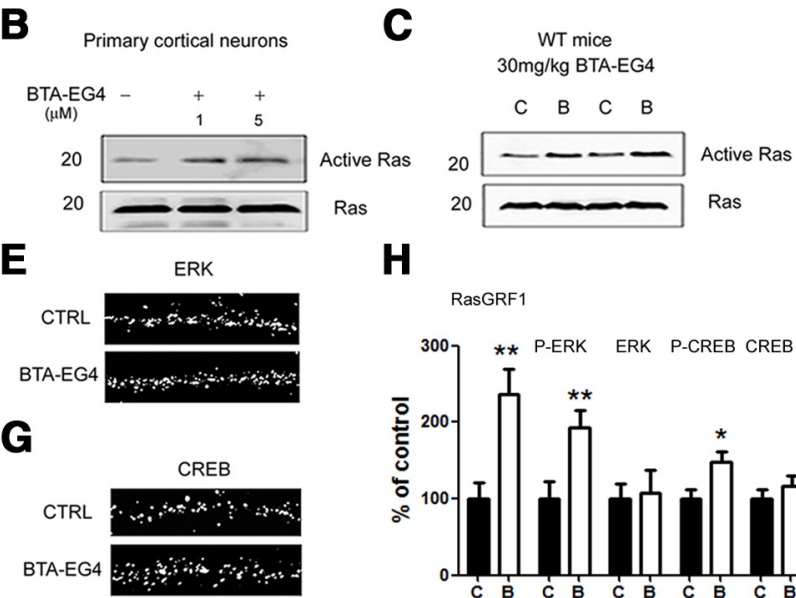

H

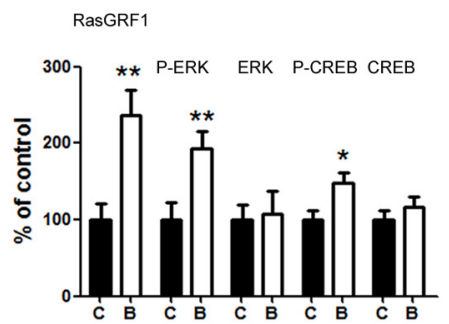

I
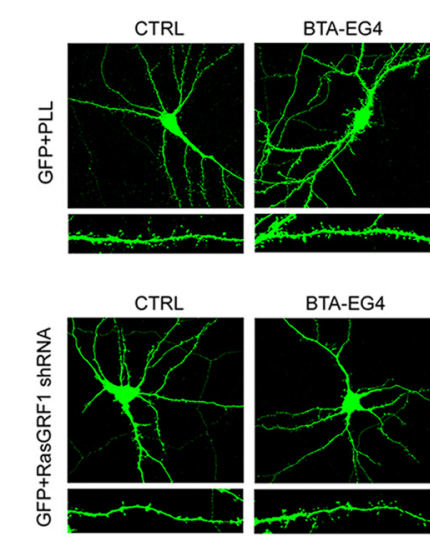

BTA-EG4



$\mathbf{J}$

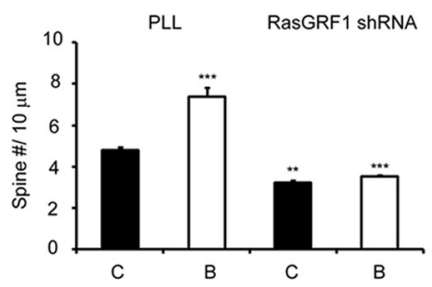

$\mathbf{K}$

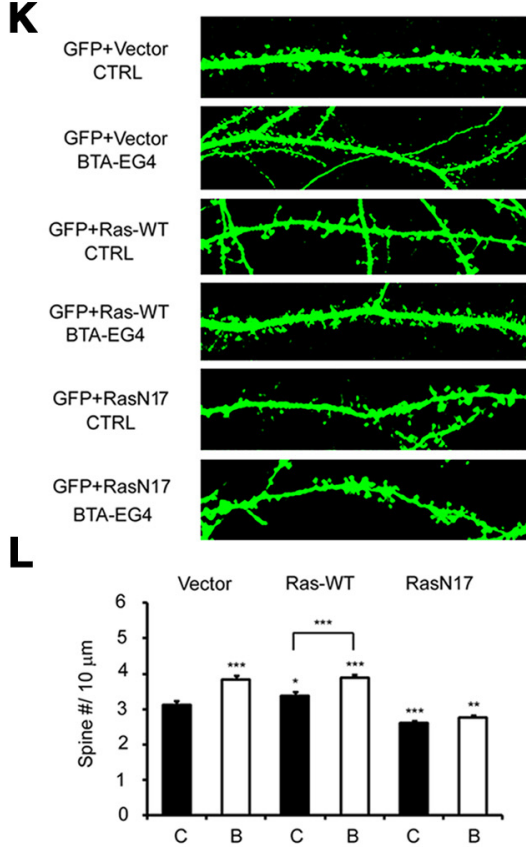

Figure 7. $\mathrm{BTA}_{-} \mathrm{EG}_{4}$ increases dendritic spine density through Ras signaling. $\boldsymbol{A}$, Cultured hippocampal neurons (DIV18) were treated with BTA-EG ${ }_{4}(5 \mu \mathrm{M})$ or control for $24 \mathrm{~h}$ and stained for RasGRF1. B, Pulldown of active Ras in primary cortical neurons using GST-Raf1-RBD ( $n=2)$. C, Pulldown of active Ras in brain lysates from wild-type mice intraperitoneally injected with BTA-EG $_{4}(30$ $\mathrm{mg} / \mathrm{kg}$ ) daily for 2 weeks, using GST-Raf1-RBD $(n=3)$. D-G, Cultured hippocampal neurons (DIV18) were treated with BTA-EG $(5 \mu \mathrm{M})$ or control for $24 \mathrm{~h}$, and stained for $p$-ERK $(\boldsymbol{D})$, ERK $(\boldsymbol{E}), p-\operatorname{CREB}(\boldsymbol{F})$, and $C R E B(\boldsymbol{G}) . \boldsymbol{A}, \boldsymbol{D}-\boldsymbol{H}$, Quantification and comparison of $\operatorname{RasGRF} 1(\boldsymbol{A}, n=15), p-\operatorname{ERK}(\boldsymbol{D}, n=21), \operatorname{ERK}(\boldsymbol{E}, n=30), p-\operatorname{CREB}(\boldsymbol{F}, n=15)$, and $\operatorname{REB}(\boldsymbol{G}, n=15)$ intensities $\left({ }^{* *} p<0.01 ;{ }^{*} p<\right.$ 0.05). I, Primary hippocampal neurons were transfected with GFP and PLL (top) or GFP and RasGRF1 shRNA (bottom) and treated with BTA-EG ${ }_{4}(5 \mu \mathrm{M})$ or control. $\boldsymbol{J}$, Quantification of dendritic spine density from $\boldsymbol{I}\left({ }^{* *} p<0.01 ;{ }^{* * *} p<0.001\right)$. $\boldsymbol{K}$, Primary hippocampal neurons were transfected with GFP and vector, GFP and Ras-WT, and GFP and RasN17, and were treated with BTA-EG $(5 \mu \mathrm{m})$ or control. $\boldsymbol{L}$, Quantification of dendritic spine density from $\boldsymbol{K}\left(n=23,{ }^{*} p<0.05 ;{ }^{* *} p<0.01 ;{ }^{* * *} p<0.001\right)$. C, Control; B, BTA-EG4.

(Figure legend continued.) mice. Left, Representative immunoblots. The blots were reprobed for $\beta$-actin, which did not show significant difference in signal between control $(C)$ and $\mathrm{BTA}^{\mathrm{E}} \mathrm{EG}_{4^{-}}$ treated $(\boldsymbol{B})$ groups $(p=0.269)$. Right, Average data of glutamate receptor signal normalized to average control (CTRL: $n=8$ mice, BTA: $n=8$ mice, $t$ test: $p>0.1$ ). There was no significant difference when the signal for each glutamate receptor antibody was normalized to the actin signal for each total homogenate sample (GluA1/ $\beta$-actin ratio: CTRL $=0.96 \pm 0.10, \mathrm{BTA}=$ $1.06 \pm 0.12, p=0.5 ;$ GluA2/ $\beta$-actin ratio: $\mathrm{CTRL}=0.98 \pm 0.09, \mathrm{BTA}=1.27 \pm 0.14, p=0.1$; GluN1/ $\beta$-actin ratio: $C T R L=0.98 \pm 0.12, \mathrm{BTA}=1.27 \pm 0.05, p=0.1 ; G l u N 2 \mathrm{~A} / \beta$-actin ratio: CTRL $=1.03 \pm 0.08, \mathrm{BTA}=1.04 \pm 0.14, p=1.0 ;$ GluN2B/ $\beta$-actin ratio: $\mathrm{CTRL}=1.02 \pm$ $0.11, \mathrm{BTA}=1.33 \pm 0.14, p=0.1)$. C, Control; B, BTA-EG4.

\section{BTA-EG 4 increases the number of functional excitatory synapses}

Next, we examined whether the increase in dendritic spine density following BTA-EG 4 treatment reflects an increase in the number of functional excitatory synapses. Primary hippocampal neurons were treated with BTA-EG $\mathrm{E}_{4}(5 \mu \mathrm{M})$ or control, and immunostained

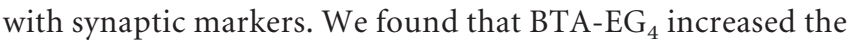
number of puncta stained for synaptophysin (presynaptic marker) and PSD-95 (postsynaptic marker) (Fig. 6A-C).

To verify that the increase in dendritic spine density and synaptic proteins reflects an increase in functional synapses, we mea- 
A

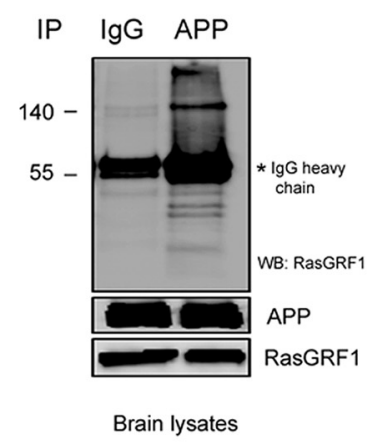

C



$\mathbf{E}$

G
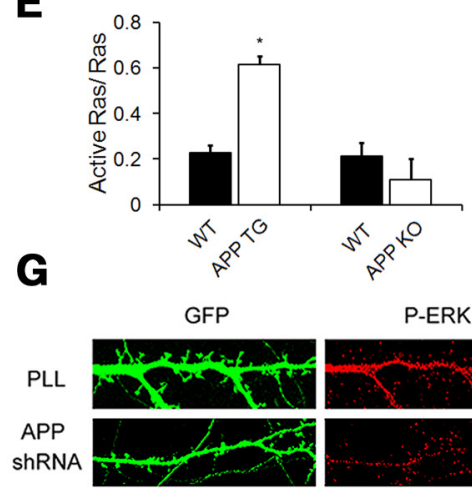

GFP
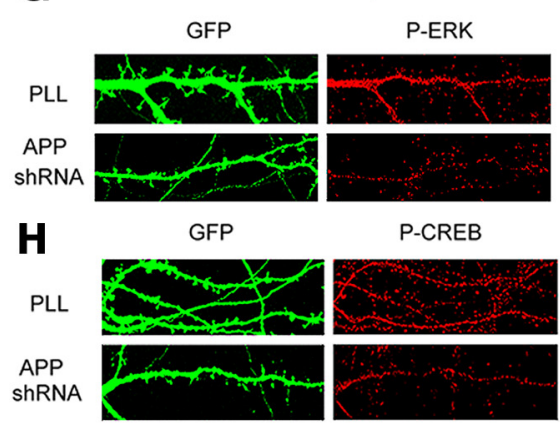

P-CREB

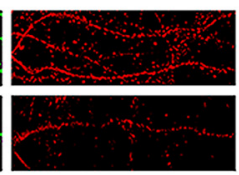

B

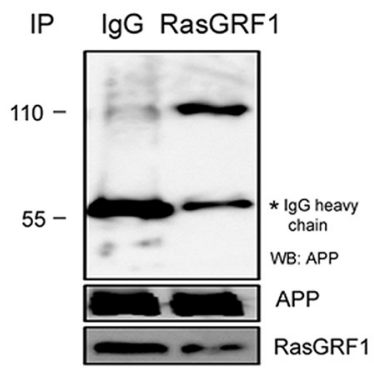

D

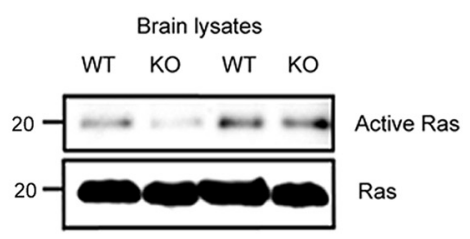

$\mathbf{F}$
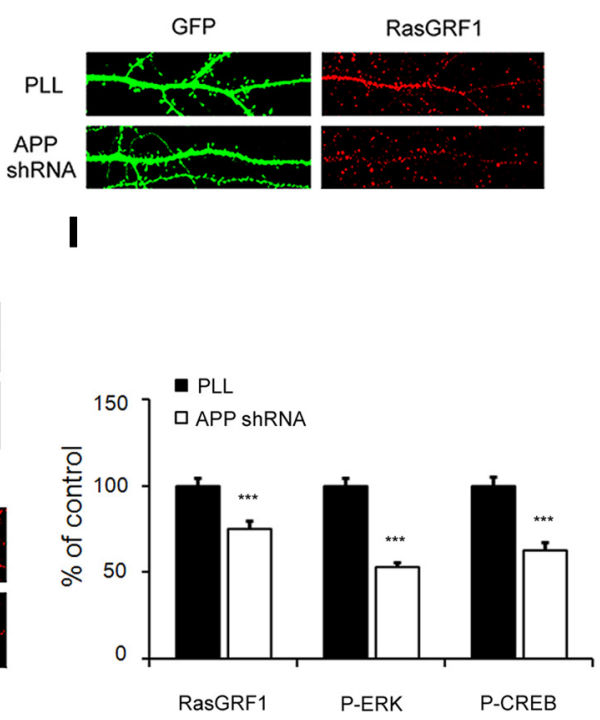

Figure 8. APP interacts with RasGRF1 and regulates Ras signaling proteins. $\boldsymbol{A}$, Brain lysates from wild-type mice were immunoprecipitated (IP) with lgG or APP, and probed with RasGRF1. B, Brain lysates from wild-type mice were immunoprecipitated with IgG or RasGRF1, and probed with APP. C, D, Pulldown of active Ras from wild-type mice (C, D,n=5), APP transgenic (TG) mice (1 month old, $\boldsymbol{C}$ ) or APP knock-out mice (D) using GST-Raf1-RBD. $\boldsymbol{E}$, Quantification of data from $\boldsymbol{C}$ and $\boldsymbol{D}$. $\boldsymbol{F}$ - $\boldsymbol{H}$, Primary hippocampal neurons were transfected with GFP and PLL or GFP and APP shRNA, then immunostained with RasGRF1 $(\boldsymbol{F}, n=25), p$-ERK $(\mathbf{G}, n=$ $25)$, and $p$-CREB $(\boldsymbol{H}, n=25)$. I, Quantification of data shown in $\left.\boldsymbol{F}-\boldsymbol{H} .{ }^{* * *} p<0.001\right)$.

sured mEPSCs from CA1 neurons in hippocampal slices following in vivo administration of BTA-EG 4 (30 mg/kg, i.p.) for 2 weeks. Consistent with an increase in functional synapses, BTA$\mathrm{EG}_{4}$ significantly increased the frequency of mEPSCs compared with vehicle-treated controls (Fig. 6D). There was no significant difference in the average mEPSC amplitude (Fig. $6 E$ ), suggesting no postsynaptic alteration in synaptic strength. Furthermore, we did not observe a change in the AMPAR/NMDAR ratio (Fig. $6 F$ ), which suggests that the new synapses likely contain both NMDAR and AMPAR at normal levels.

To test whether the increase in functional excitatory synapses occurs via cell surface recruitment of glutamate receptors, we performed steady-state surface biotinylation using acute hippocampal slices obtained from mice injected with BTA-EG $4(30 \mathrm{mg} / \mathrm{kg})$ or control vehicle for 2 weeks. Both the cell surface and total levels of major AMPAR subunits GluA1 and GluA2, as well as NMDAR subunits GluN1, GluN2A, and GluN2B, were quantified. There was no significant change in cell surface or total expression of any of these proteins in hippocampal slices from BTA$\mathrm{EG}_{4}$-treated mice (Fig. 6G-J). These data suggest that BTA-EG E $_{4}$ does not regulate cell surface or total expression of AMPAR or NMDAR. Hence, the increase in the number of functional synapses is likely due to lateral recruitment of existing cell surface glutamate receptors to new spines.

\section{BTA-EG 4 alters synapse formation through Ras signaling}

We next investigated the molecular mechanism by which BTA-EG 4 may alter dendritic spine formation. Ras, a small GTPase, is involved in dendritic spine formation and synaptic delivery of AMPA receptors (Zhu et al., 2002; Lee et al., 2011). Moreover, abnormal Ras signaling is associated with neurodegenerative disease, causing cognitive impairments and learning deficits (Stornetta and Zhu, 2011). Thus, we initially investigated the effect of BTA-EG $\mathrm{E}_{4}$ on Ras signaling by treating primary hippocampal neurons with BTA-EG $_{4}(5 \mu \mathrm{M})$ or control for $24 \mathrm{~h}$. Interestingly, we found that $\mathrm{BTA}-\mathrm{EG}_{4}$ increased levels of RasGRF1, a guanine nucleotide exchange factor involved in Ras activation (Lee et al., 2010), as measured by immunofluorescence (Fig. $7 A, H)$. Further, levels of active Ras were elevated following BTA-EG 4 treatment $(5 \mu \mathrm{M})$ in primary cortical neurons (Fig. $7 \mathrm{~B}, \mathrm{H}$ ) and following BTA$\mathrm{EG}_{4}$ treatment $(30 \mathrm{mg} / \mathrm{kg})$ in wild-type mice (Fig. $7 C, H$ ). We also examined whether BTA-EG ${ }_{4}$ can alter the activity of downstream Ras signaling proteins, including $p$-ERK and $p$-CREB. We found that BTA-EG $4(5 \mu \mathrm{M})$ increased the phosphorylation of ERK and CREB, the active forms of the signaling molecules downstream of Ras, without altering total ERK or CREB levels (Fig. 7D-H).

To examine whether the effect of $\mathrm{BTA}-\mathrm{EG}_{4}$ on dendritic spine formation is Ras dependent, primary hippocampal neurons were transfected with GFP and RasGRF1 shRNA, or GFP and PLL. After $24 \mathrm{~h}$, we treated with BTA-EG $4(5 \mu \mathrm{M})$ or control for another $24 \mathrm{~h}$, and spine density was measured using immunofluorescence. Consistent with our findings above, BTA-EG 4 significantly increased dendritic spine density; however, RasGRF1 knockdown prevented the effect of BTA-EG $\mathrm{B}_{4}$ on dendritic spine formation (Fig. $7 \mathrm{I}, \mathrm{J}$ ). In addition, primary hippocampal neurons were transfected with GFP and empty vector, GFP and Ras-WT, or GFP and RasN17 (inactive Ras mutant). After $24 \mathrm{~h}$, we then treated neurons with BTA-EG 4 $\mu \mathrm{M}$ ) or control for $24 \mathrm{~h}$, and spine density was measured. Ras-WT

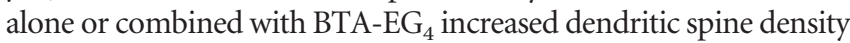
compared with control (Fig. $7 K, L$ ). RasN17 decreased dendritic

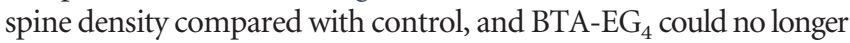
increase dendritic spine density in the presence of RasN17 (Fig. $7 K, L$ ). These results suggest that Ras signaling is necessary for mediating the increase in dendritic spine density conferred by BTA-EG . $_{4}$ 


\section{APP interacts with RasGRF1 and regulates Ras signaling proteins} Since we observed that BTA-EG 4 functions through APP (Fig. 5) and requires Ras signaling to increase spine density (Fig. 7), we examined whether APP can increase spine density through Ras signaling. To test this, we examined whether APP can interact with RasGRF1 by immunoprecipitating APP from brain lysates of wild-type mice, and probing for RasGRF1 (Fig. 8A). Interestingly, we found that APP coimmunoprecipitates with RasGRF1 (Fig. 8A). Results from immunoprecipitating RasGRF1 and probing for APP also indicated that RasGRF1 coimmunoprecipitates with APP (Fig. 8B). Our results indicate that RasGRF1 associates with APP in vivo.

Next, to examine whether APP can alter RasGRF1 levels, we examined the effect of APP on Ras activity in APP transgenic mice and APP KO mice using a GST pull-down assay (Fig. $8 C-E$ ). We found that Ras activity was elevated in 1-month-old APP transgenic mice (overexpressing APP without $\mathrm{A} \beta$ pathology at 1 month), but decreased in 10-month-old APP KO mice, compared with wild-type mice (Fig. 8C-E). Furthermore, we examined whether APP can alter the activity of downstream Ras signaling proteins ERK and CREB. First, to verify the effect of APP on Ras signaling, primary hippocampal neurons were transfected with GFP and PLL or GFP and APP shRNA, and then immunostained against RasGRF1. Knockdown of APP significantly decreased the levels of RasGRF1 compared with control vector (Fig. $8 F, I$ ). We then immunostained primary hippocampal neurons transfected with GFP and PLL or GFP and APP shRNA against $p$-ERK and $p$-CREB. We found that knockdown of APP decreased the phosphorylation of ERK and CREB compared with control vector (Fig. 8G-I). These data suggest that APP may regulate dendritic spine formation through increases in Ras activity and downstream Ras signaling pathways.

\section{BTA-EG 4 requires APP to alter Ras signaling}

Since we observed that BTA-EG ${ }_{4}$ and APP could possibly regulate dendritic spine density through Ras-dependent mechanisms, we then examined whether BTA-EG 4 requires APP to modulate Ras signaling. To test this hypothesis, primary hippocampal neurons were transfected with GFP and APP shRNA or GFP and APP, treated with control or BTA-EG $4(5 \mu \mathrm{M})$, then immunostained against RasGRF1 (Fig. 9A,B). We found that knockdown of APP did not increase RasGRF1 following BTA-EG 4 treatment compared with control, while overexpression of APP significantly increased RasGRF1 following BTA-EG E $_{4}$ treatment compared with control (Fig. 9A,B).

Next, we investigated whether BTA-EG ${ }_{4}$ can alter Ras activity in APP KO mice by injecting control or BTA-EG for $_{2}$ weeks. We found that BTA-EG $\mathrm{B}_{4}$-injected APP KO mice did not have altered Ras activity (Fig. 9C). Further, we examined the effect of BTA$\mathrm{EG}_{4}$ on downstream Ras signaling in the presence or absence of
APP. For this experiment, primary hippocampal neurons were transfected with GFP and APP shRNA or APP, treated with BTA$\mathrm{EG}_{4}$ or control, and then immunostained against $p$-ERK or $p$-CREB. We found that BTA-EG Bas $_{4}$ ineffective at increasing $p$-ERK or $p$-CREB following knockdown of APP, while overexpression of APP significantly increased $p$-ERK and $p$-CREB with BTA-EG ${ }_{4}$ treatment compared with control (Fig. 9D-G). These


dependent signaling.

\section{Discussion}

In the present study, we demonstrate that the $\mathrm{A} \beta$-targeting molecule $\mathrm{BTA}-\mathrm{EG}_{4}$ reduces $\mathrm{A} \beta$ levels by facilitating cell surface expression of APP (Fig. 1). Wild-type mice treated with BTA-EG exhibited improved cognitive performance without enhancement of hippocampal LTP (Figs. 2, 3). Additionally, BTA-EG promotes dendritic spine density, which was accompanied by an increase in the number of functional synapses as determined by elevated mEPSC frequency. Moreover, BTA-EG 4 regulates dendritic spine formation, potentially by increasing the activity of Ras-ERK signaling proteins through APP (Figs. 7-9). Together, these results strongly suggest that BTA-EG ${ }_{4}$ works through APP to increase dendritic spine density via a Ras ERK-dependent mechanism. In addition, $\mathrm{BTA}_{\mathrm{A}} \mathrm{EG}_{4}$ warrants further investigation to determine its effect in mouse models of $\mathrm{AD}$.

BTA-EG ${ }_{4}$ treatment regulates APP metabolism, resulting in reduced $A \beta$ levels and increased cell surface APP. It is known that $\beta$-secretase cleavage of APP forms A $\beta$ along the intracellular en- 
dosomal pathway. Conversely, $\alpha$-secretase cleavage of APP occurs at the cell surface and prevents $A \beta$ production (Hyman, 2011). Because BTA-EG $\mathrm{E}_{4}$ did not alter the levels of $\mathrm{A} \beta$ degradation enzymes (i.e., insulin-degrading enzyme, neprilysin; data not shown), we believe BTA-EG ${ }_{4}$ decreases $\mathrm{A} \beta$ levels by specifically increasing cell surface levels of APP, and thus, favoring processing of APP by $\alpha$-secretase cleavage over processing by $\beta$-secretase.

Several recent studies have shown that $\mathrm{A} \beta$ aggregation is correlated with deficits in learning and memory, and therapies that decrease $\mathrm{A} \beta$ can rescue these deficits (Loane et al., 2009; Chang et al., 2011). For instance, $\gamma$-secretase inhibitor (DAPT)-injected mice had decreased $A \beta$ levels and improved behavioral performance after traumatic brain injury (Loane et al., 2009). Other studies using mouse models of $\mathrm{AD}$ showed reduced $\mathrm{A} \beta$ levels after treatment with either $\beta$-secretase or histone deacetylase (HDAC) inhibitors (Chang et al., 2011; Ricobaraza et al., 2011). These therapies were also able to prevent or improve memory deficits in $\mathrm{AD}$ mice. Furthermore, $\gamma$-secretase and HDAC inhibitors increase LTP, increase dendritic spine density, and improve cognitive performance (Townsend et al., 2010; Haettig et al., 2011). In contrast to these results, we found that while BTA-EG ${ }_{4}$ had positive effects on cognitive performance and dendritic spine density, it did so without a correlated increase in the magnitude of LTP at both SC and TA inputs to CA1 (Fig. 3). This finding implies that BTA-EG improves cognitive performance through an LTP-independent mechanism, and suggests that targeting spine density alone may be sufficient to improve cognitive function.

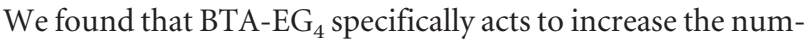
ber of functional synapses, but individual synapses are not stronger. The lack of an increase in LTP magnitude suggests that the new synapses are available for synaptic plasticity, but there is no enhancement of LTP due to the addition of new synapses. While our LTP findings defy the conventional interpretation of the role of LTP in memory formation, it is not an isolated case. Indeed, in the PAK transgenic model, decreased dendritic spine density was associated with a decrease in cognitive performance, but an enhancement of LTP magnitude (Hayashi et al., 2004). Combined with our results, this suggests that an increase in the number of dendritic spines and functional synapses confer benefits to cognitive function. The reduction in LTP magnitude seen in some cases may be a homeostatic adjustment to the increase in synapse number. For example, higher synaptic density may increase the LTP induction threshold to prevent overexcitation of neuronal activity. This presents an interesting point by implying that creating new synapses may benefit cognitive function not by enhancing LTP at individual synapses, but by allowing more synaptic contact points to form along the dendrite for potential information storage. It is of interest to note that some of the APP transgenic $\mathrm{AD}$ mouse models display larger LTP in younger age (Marchetti and Marie, 2011; Wang et al., 2012). It would be of

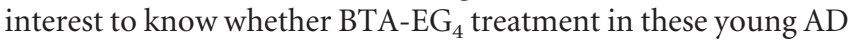
mouse models would show beneficial effects. While BTA-EG significantly increased dendritic spine density in cortical layers II/III and the hippocampal CA1 region, this occurred without changes in dendritic spine morphology. Longer and thinner dendritic spines are characterized as immature "plastic" spines, while shorter and wider dendritic spines are characterized as mature "memory" spines (Kasai et al., 2002; Yasumatsu et al., 2008).

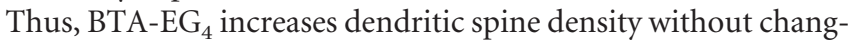
ing the proportion of immature and mature spines.

Here, we investigated the molecular mechanism by which BTA- $-\mathrm{EG}_{4}$ regulates dendritic spine density. One possibility is that

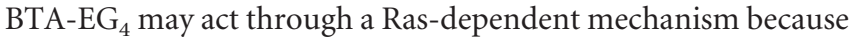
Ras signaling not only plays an important role in dendritic spine formation, but also in neuronal degeneration (Saini et al., 2009; Ye and Carew, 2010; Lee et al., 2011; Stornetta and Zhu, 2011). For instance, $\mathrm{AD}$ mice models have increased synaptic depression, which results in decreased activity and levels of RasGRF1, as well as downstream Ras signaling proteins. In contrast, $\mathrm{AD}$ patients have increased activity of Rap effectors, including $p$-JNK, which is accompanied by the removal of synaptic AMPA receptors (Savage et al., 2002; Zhu et al., 2002; Stornetta and Zhu, 2011). Interestingly, we observed that BTA-EG 4 promotes RasERK signaling (Fig. 7). BTA-EG 4 treatment increased RasGRF1 levels and Ras activity as well as activation of downstream Ras signaling proteins, including $p$-ERK. We found that Ras activity is necessary for spinogenesis induced by BTA-EG ${ }_{4}$, which suggests that one of the main signaling pathways involved in BTA-EG action is via its ability to activate Ras. Therefore, $\mathrm{BTA}-\mathrm{EG}_{4}$ has the potential to reverse the decrease in Ras signaling seen in AD.

How does BTA-EG $\mathrm{B}_{4}$ activate Ras signaling to increase spine density? One possibility is that BTA-EG $\mathrm{B}_{4}$ binds directly to $\mathrm{A} \beta$ to prevent negative functional effects, resulting in protection against synapse loss. We also have data to demonstrate that BTA$\mathrm{EG}_{4}$ promotes cell surface expression of APP, which is known to increase dendritic spine formation (Lee et al., 2010). Here, our novel finding provides evidence that APP promotes spinogenesis through direct or indirect interaction with RasGRF1 to increase Ras activity and downstream signaling to promote spinogenesis (Fig. 8). Furthermore, the action of BTA-EG $\mathrm{EG}_{4}$ on dendritic spine formation and Ras activity both required APP (Fig. 9). While this does not rule out the possibility that BTA-EG $\mathrm{B}_{4}$ acts via neutralizing $\mathrm{A} \beta$, the more parsimonious explanation is that $\mathrm{BTA}-\mathrm{EG}_{4}$ promotes APP signaling to enhance Ras-dependent spinogenesis. Whether the effect of BTA-EG $\mathrm{E}_{4}$ on APP signaling is strictly through enhancing cell surface APP levels or preventing $\beta$-cleavage of APP, perhaps via direct binding to the $\mathrm{A} \beta$ domain of APP, remains to be investigated. Nevertheless, there is evidence that $\mathrm{A} \beta$ and full-length APP often produce opposite signaling (Hoe et al., 2012); hence, the dual role of $B T A-E_{4}$ in reducing $\mathrm{A} \beta$ and promoting APP signaling is likely conferring benefit to synaptic and cognitive function.

Together, our results strongly suggest that $\mathrm{BTA}-\mathrm{EG}_{4}$ treatment decreases $\mathrm{A} \beta$ levels and improves cognitive performance. Moreover, BTA-EG 4 increases dendritic spine density through APP- and Ras-dependent mechanisms. Thus, this novel small molecule exhibits potential as a drug candidate for $\mathrm{AD}$ treatment and warrants further studies to determine its effect in mouse models of AD.

\section{References}

Capule CC, Yang J (2012) Enzyme-Linked Immunosorbent Assay-Based Method to Quantify the Association of Small Molecules with Aggregated Amyloid Peptides. Analytical Chemistry 84:1786-1791. CrossRef Medline

Chang WP, Huang X, Downs D, Cirrito JR, Koelsch G, Holtzman DM, Ghosh AK, Tang J (2011) Beta-secretase inhibitor GRL-8234 rescues agerelated cognitive decline in APP transgenic mice. FASEB J 25:775-784. CrossRef Medline

Chételat G, Villemagne VL, Pike KE, Ellis KA, Ames D, Masters CL, Rowe CC (2012) Relationship between memory performance and beta-amyloid deposition at different stages of Alzheimer's disease. Neurodegener Dis 10:141-144. CrossRef Medline

Finder VH, Glockshuber R (2007) Amyloid-beta aggregation. Neurodegener Dis 4:13-27. CrossRef Medline

Habib LK, Lee MT, Yang J (2010) Inhibitors of catalase-amyloid interac- 
tions protect cells from beta-amyloid-induced oxidative stress and toxicity. J Biol Chem 285:38933-38943. CrossRef Medline

Haettig J, Stefanko DP, Multani ML, Figueroa DX, McQuown SC, Wood MA (2011) HDAC inhibition modulates hippocampus-dependent longterm memory for object location in a CBP-dependent manner. Learn Mem 18:71-79. CrossRef Medline

Hayashi ML, Choi SY, Rao BS, Jung HY, Lee HK, Zhang D, Chattarji S, Kirkwood A, Tonegawa S (2004) Altered cortical synaptic morphology and impaired memory consolidation in forebrain-specific dominantnegative PAK transgenic mice. Neuron 42:773-787. CrossRef Medline

Hoe HS, Lee HK, Pak DT (2012) The upside of APP at synapses. CNS Neurosci Ther 18:47-56. CrossRef Medline

Huse JT, Pijak DS, Leslie GJ, Lee VM, Doms RW (2000) Maturation and endosomal targeting of beta-site amyloid precursor protein-cleaving enzyme. The Alzheimer's disease beta-secretase. J Biol Chem 275:33729-33737. CrossRef Medline

Hyman BT (2011) Amyloid-dependent and amyloid-independent stages of Alzheimer disease. Arch Neurol 68:1062-1064. CrossRef Medline

Inbar P, Li CQ, Takayama SA, Bautista MR, Yang J (2006) Oligo(ethylene glycol) derivatives of thioflavin $\mathrm{T}$ as inhibitors of protein-amyloid interactions. Chembiochem 7:1563-1566. CrossRef Medline

Iyer M, Mishra R, Han Y, Hopfinger AJ (2002) Predicting blood-brain barrier partitioning of organic molecules using membrane-interaction QSAR analysis. Pharmaceut Res 19:1611-1621. CrossRef

Kandel ER (2001) The molecular biology of memory storage: a dialogue between genes and synapses. Science 294:1030-1038. CrossRef Medline

Kasai H, Matsuzaki M, Noguchi J, Yasumatsu N (2002) Dendritic spine structures and functions. Nihon Shinkei Seishin Yakurigaku Zasshi 22: 159-164. Medline

Lee KJ, Moussa CE, Lee Y, Sung Y, Howell BW, Turner RS, Pak DT, Hoe HS (2010) Beta amyloid-independent role of amyloid precursor protein in generation and maintenance of dendritic spines. Neuroscience 169:344-356. CrossRef Medline

Lee KJ, Hoe HS, Pak DT (2011) Plk2 Raps up Ras to subdue synapses. Small GTPases 2:162-166. CrossRef Medline

Loane DJ, Pocivavsek A, Moussa CE, Thompson R, Matsuoka Y, Faden AI, Rebeck GW, Burns MP (2009) Amyloid precursor protein secretases as therapeutic targets for traumatic brain injury. Nat Med 15:377-379. CrossRef Medline

Lustbader JW, Cirilli M, Lin C, Xu HW, Takuma K, Wang N, Caspersen C, Chen X, Pollak S, Chaney M, Trinchese F, Liu S, Gunn-Moore F, Lue LF, Walker DG, Kuppusamy P, Zewier ZL, Arancio O, Stern D, Yan SS, et al (2004) ABAD directly links Abeta to mitochondrial toxicity in Alzheimer's disease. Science 304:448-452. CrossRef Medline

Marchetti C, Marie H (2011) Hippocampal synaptic plasticity in Alzheimer's disease: what have we learned so far from transgenic models? Rev Neurosci 22:373-402. CrossRef Medline

Minami SS, Cordova A, Cirrito JR, Tesoriero JA, Babus LW, Davis GC, Dakshanamurthy S, Turner RS, Pak DTs, Rebeck GW, Paige M, Hoe HS (2010) ApoE mimetic peptide decreases Abeta production in vitro and in vivo. Mol Neurodegener 5:16. CrossRef Medline

Morgado-Bernal I (2011) Learning and memory consolidation: linking molecular and behavioral data. Neuroscience 176:12-19. CrossRef Medline

Nakashiba T, Young JZ, McHugh TJ, Buhl DL, Tonegawa S (2008) Trans- genic inhibition of synaptic transmission reveals role of CA3 output in hippocampal learning. Science 319:1260-1264. CrossRef Medline

Nicoll JA, Wilkinson D, Holmes C, Steart P, Markham H, Weller RO (2003) Neuropathology of human Alzheimer disease after immunization with amyloid-beta peptide: a case report. Nat Med 9:448-452. CrossRef Medline

Orgogozo JM, Gilman S, Dartigues JF, Laurent B, Puel M, Kirby LC, Jouanny P, Dubois B, Eisner L, Flitman S, Michel BF, Boada M, Frank A, Hock C (2003) Subacute meningoencephalitis in a subset of patients with AD after Abeta42 immunization. Neurology 61:46-54. CrossRef Medline

Pak DT, Yang S, Rudolph-Correia S, Kim E, Sheng M (2001) Regulation of dendritic spine morphology by SPAR, a PSD-95-associated RapGAP. Neuron 31:289-303. CrossRef Medline

Rall W (1969) Time constants and electrotonic length of membrane cylinders and neurons. Biophys J 9:1483-1508. CrossRef Medline

Reiss K, Ludwig A, Saftig P (2006) Breaking up the tie: disintegrin-like metalloproteinases as regulators of cell migration in inflammation and invasion. Pharmacol Ther 111:985-1006. CrossRef Medline

Ricobaraza A, Cuadrado-Tejedor M, Garcia-Osta A (2011) Long-term phenylbutyrate administration prevents memory deficits in $\mathrm{Tg} 2576$ mice by decreasing Abeta. Front Biosci (Elite Ed) 3:1375-1384. Medline

Saini DK, Chisari M, Gautam N (2009) Shuttling and translocation of heterotrimeric G proteins and Ras. Trends Pharmacol Sci 30:278-286. CrossRef Medline

Savage MJ, Lin YG, Ciallella JR, Flood DG, Scott RW (2002) Activation of c-Jun N-terminal kinase and p38 in an Alzheimer's disease model is associated with amyloid deposition. J Neurosci 22:3376-3385. Medline

Selkoe DJ (2011) Resolving controversies on the path to Alzheimer's therapeutics. Nat Med 17:1060-1065. CrossRef Medline

Stornetta RL, Zhu JJ (2011) Ras and Rap signaling in synaptic plasticity and mental disorders. Neuroscientist 17:54-78. CrossRef Medline

Subbarao KV, Richardson JS, Ang LC (1990) Autopsy samples of Alzheimer's cortex show increased peroxidation in vitro. J Neurochem 55:342345. CrossRef Medline

Townsend M, Qu Y, Gray A, Wu Z, Seto T, Hutton M, Shearman MS, Middleton RE (2010) Oral treatment with a gamma-secretase inhibitor improves long-term potentiation in a mouse model of Alzheimer's disease. J Pharmacol Exp Ther 333:110-119. CrossRef Medline

VanGuilder HD, Farley JA, Yan H, Van Kirk CA, Mitschelen M, Sonntag WE, Freeman WM (2011) Hippocampal dysregulation of synaptic plasticityassociated proteins with age-related cognitive decline. Neurobiol Dis 43: 201-212. CrossRef Medline

Wang H, Megill A, He K, Kirkwood A, Lee HK (2012) Consequences of inhibiting amyloid precursor protein processing enzymes on synaptic function and plasticity. Neural Plast 2012:272374. CrossRef Medline

Yasumatsu N, Matsuzaki M, Miyazaki T, Noguchi J, Kasai H (2008) Principles of long-term dynamics of dendritic spines. J Neurosci 28:1359213608. CrossRef Medline

Ye X, Carew TJ (2010) Small G protein signaling in neuronal plasticity and memory formation: the specific role of ras family proteins. Neuron 68: 340-361. CrossRef Medline

Zhu JJ, Qin Y, Zhao M, Van Aelst L, Malinow R (2002) Ras and Rap control AMPA receptor trafficking during synaptic plasticity. Cell 110:443-455. CrossRef Medline 